Article

\title{
Variable Magnitude and Intensity of Strombolian Explosions: Focus on the Eruptive Processes for a First Classification Scheme for Stromboli Volcano (Italy)
}

\author{
Sonia Calvari ${ }^{1, *} \mathbb{( D}$, Flora Giudicepietro ${ }^{2}$, Federico Di Traglia ${ }^{3}{ }^{\circledR}$, Alessandro Bonaccorso ${ }^{1}(\mathbb{D}$, \\ Giovanni Macedonio $^{2}$ and Nicola Casagli ${ }^{3,4}$ \\ 1 Istituto Nazionale di Geofisica e Vulcanologia, Osservatorio Etneo-Sezione di Catania, 95125 Catania, Italy; \\ alessandro.bonaccorso@ingv.it \\ 2 Istituto Nazionale di Geofisica e Vulcanologia, Osservatorio Vesuviano, 80125 Napoli, Italy; \\ flora.giudicepietro@ingv.it (F.G.); giovanni.macedonio@ingv.it (G.M.) \\ 3 Dipartimento di Scienze della Terra, Universitá degli Studi di Firenze, 50121 Firenze, Italy; \\ federico.ditraglia@unifi.it (F.D.T.); nicola.casagli@inogs.it (N.C.) \\ 4 National Institute of Oceanography and Applied Geophysics-OGS, 30010 Trieste, Italy \\ * Correspondence: sonia.calvari@ingv.it
}

\section{check for} updates

Citation: Calvari, S.; Giudicepietro, F.; Di Traglia, F.; Bonaccorso, A.; Macedonio, G.; Casagli, N. Variable Magnitude and Intensity of Strombolian Explosions: Focus on the Eruptive Processes for a First Classification Scheme for Stromboli Volcano (Italy). Remote Sens. 2021, 13, 944. https://doi.org/10.3390/ rs13050944

Academic Editor: Fumio Yamazaki

Received: 9 February 2021

Accepted: 25 February 2021

Published: 3 March 2021

Publisher's Note: MDPI stays neutral with regard to jurisdictional claims in published maps and institutional affiliations.

Copyright: (c) 2021 by the authors. Licensee MDPI, Basel, Switzerland. This article is an open access article distributed under the terms and conditions of the Creative Commons Attribution (CC BY) license (https:// creativecommons.org/licenses/by/ $4.0 /)$.

\begin{abstract}
Strombolian activity varies in magnitude and intensity and may evolve into a threat for the local populations living on volcanoes with persistent or semi-persistent activity. A key example comes from the activity of Stromboli volcano (Italy). The "ordinary" Strombolian activity, consisting in intermittent ejection of bombs and lapilli around the eruptive vents, is sometimes interrupted by high-energy explosive events (locally called major or paroxysmal explosions), which can affect very large areas. Recently, the 3 July 2019 explosive paroxysm at Stromboli volcano caused serious concerns in the local population and media, having killed one tourist while hiking on the volcano. Major explosions, albeit not endangering inhabited areas, often produce a fallout of bombs and lapilli in zones frequented by tourists. Despite this, the classification of Strombolian explosions on the basis of their intensity derives from measurements that are not always replicable (i.e., field surveys). Hence the need for a fast, objective and quantitative classification of explosive activity. Here, we use images of the monitoring camera network, seismicity and ground deformation data, to characterize and distinguish paroxysms, impacting the whole island, from major explosions, that affect the summit of the volcano above $500 \mathrm{~m}$ elevation, and from the persistent, mild explosive activity that normally has no impact on the local population. This analysis comprises 12 explosive events occurring at Stromboli after 25 June 2019 and is updated to 6 December 2020.
\end{abstract}

Keywords: Stromboli volcano; paroxysmal explosions; major explosive events; ground and remote sensing monitoring; classification of mild Strombolian events

\section{Introduction}

Strombolian activity is characterized by explosive transients of variable intensity, from pyroclast-free gas explosions (puffing) to intense explosions, with the formation of a few-km-high eruptive columns, ballistic ejection, and occasional generation of pyroclastic density currents [1-6]. The classification, as well as the understanding of the dynamics that trigger explosions of different intensities, is fundamental for the hazard assessment in areas characterized by Strombolian activity, both for territorial planning and for forecasting through monitoring and surveillance. A multi-parametric approach, combining geophysical and volcanological monitoring data with remote sensing techniques, is fundamental in order to find an objective as possible way to classify these transient explosions.

The best site to investigate this activity is Stromboli (Italy), known as the "Lighthouse of the Mediterranean" for its persistent explosive activity, characterized by bursts of incandescent ejecta occurring every few minutes [4,7-9], and clearly visible especially at 
night by sailors. Stromboli volcano is the easternmost of the islands comprising the Aeolian Archipelago volcanic arc in the south Tyrrhenian Sea (Figure 1a). It is $924 \mathrm{~m}$ high above sea level (a.s.l.; Figure 1b) and extends below the sea down to $2000 \mathrm{~m}$ depth, reaching a total elevation of $\sim 3000 \mathrm{~m}$ [10]. Explosions occur from vents located within the summit crater terrace depression at $\sim 750 \mathrm{~m}$ elevation (Figure 1c), which is $\sim 300 \mathrm{~m}$ long in a NE-SW direction, $\sim 50 \mathrm{~m}$ wide and $\sim 50 \mathrm{~m}$ deep (Figure 1c). Three crater areas are located within the summit depression: the NE crater zone (NEC), the Central crater zone (CC) and the SW crater zone (SWC), each of them comprising a variable number of active vents (Figure 1c).

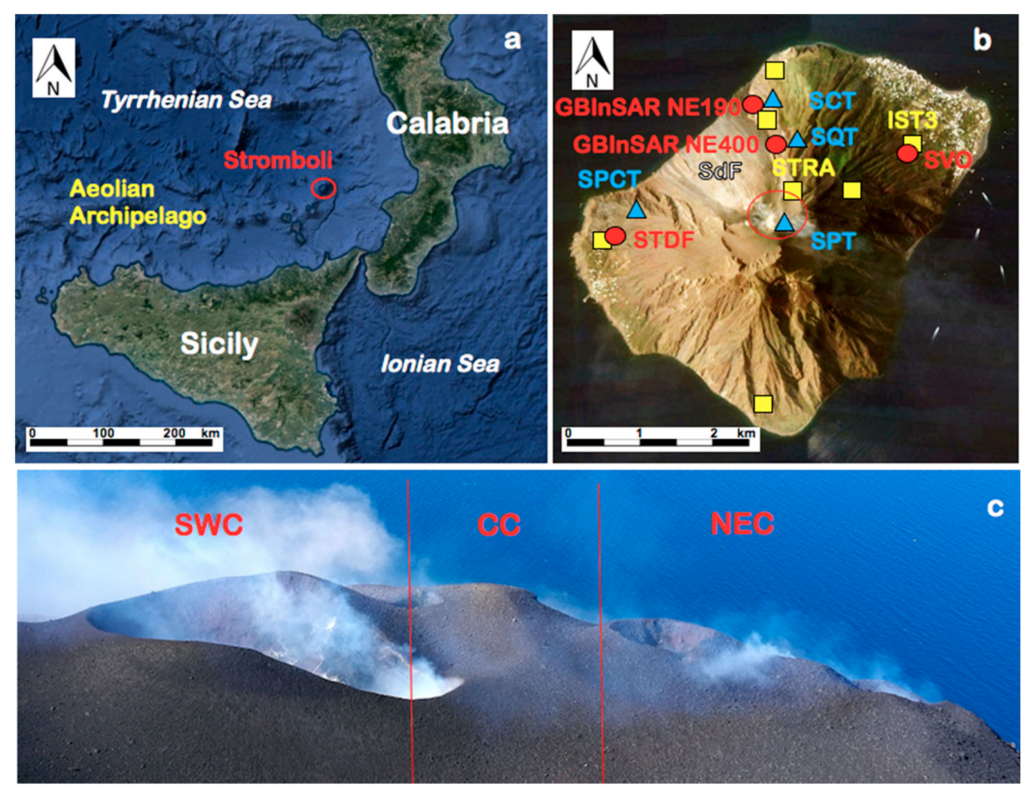

Figure 1. (a) Google map of southern Italy, with the red circle showing the position of Stromboli volcano, at the NE end of the Aeolian Archipelago. (b) Stromboli island with the position and labels of the monitoring instruments used in this study. The blue triangles are the monitoring cameras, with SPT being the thermal camera located at Il Pizzo Sopra La Fossa viewpoint. The SCV camera is located in the same place as SCT, and the SQV camera is in the same place as SQT; the red circles are the GBInSARs, the tilt (STDF) and strainmeter (SVO) stations; the yellow squares are the seismic stations. The empty red circle outlines the position of the summit craters displayed in frame c. $\mathrm{SdF}=$ Sciara del Fuoco slope. (c) View from South and from Il Pizzo Sopra La Fossa viewpoint of Stromboli summit craters; photo taken on 21 February 2020, showing the names of the active crater areas. NEC $=$ NE Crater zone; CC $=$ Central Crater zone; SWC $=$ SW Crater zone. The field of view is about $300 \mathrm{~m}$ wide. Photo courtesy of F. Ciancitto, INGV.

The Strombolian activity of Stromboli is characterized by explosive transients of short duration ( $<10 \mathrm{~s}$, obtained from the monitoring cameras) and small eruptive ash columns $(<100 \mathrm{~m})$, with variable intensity and frequency [11], which depend on the supply rate of the deeper system towards the surface $[8,12-14]$. This volcano gave its name to the Strombolian explosive activity, with mild explosions typical of basaltic explosive volcanism, that often feature at the summit of Yasur (Vanuatu), Piton de la Fournaise (La Réunion), Shishaldin (Alaska), Fuego (Guatemala), Nyiragongo (R.D. Congo), Masaya (Nicaragua), Turrialba (Costa Rica), Etna (Italy), Kilauea (Hawaii), and several other open conduit basaltic volcanoes [15-24].

The persistent, mild explosive activity of Stromboli is sometimes interrupted by more intense and powerful explosions. Several classifications of this "more intense" activity have been proposed over time. The first was put forward by Barberi et al. [12], who distinguished three types of explosions: in addition to the "ordinary" or persistent activity (Figure 2a), major (Figure 2b) and paroxysmal explosions (Figure 2c) were identified, depending on size, covering a broad variability in intensity and magnitude, with the latter 
having significantly larger intensities ( $\left.>10^{6} \mathrm{~kg} / \mathrm{s}\right)$ than the former $\left(10^{4} \mathrm{~kg} / \mathrm{s}\right)$ [25]. Major explosions (Figure $2 b$ ) normally involve more than one crater zone, may follow partial obstructions of the summit vents, and cause the rise of a mixture of spatter, bombs, ash and gas forming an eruptive column that extends $>300 \mathrm{~m}$ above the vents, with fallout of bombs and ash up to several hundred meters from the crater area [12,26,27]. More rarely, the volcano is the site of extremely powerful explosions, called "paroxysms", that result in eruptive columns rising a few $\mathrm{km}$ above the craters (Figure 2c) and causing fires and damages to the populated villages on the lower flanks of the volcano, 2.0-2.5 km away from the summit craters [12,28-33]. Paroxysms are also characterized by greater volumes of emitted materials, higher muzzle velocities, and higher mass discharge rates $[12,34,35]$. Besides major eruptions (Figure $2 b$ ), there is a complete range of intermediate events from the persistent "ordinary" mild Strombolian activity (Figure 2a) to the most powerful paroxysms (Figure 2c). Occasional flank fissures discharging lava flows within the Sciara del Fuoco (SdF) barren NW slope may also occur (Figure 1b). Lava fountains are generally not common and of short duration (minutes; [12,31]), whereas the periods without eruptive activity are extremely rare [12].
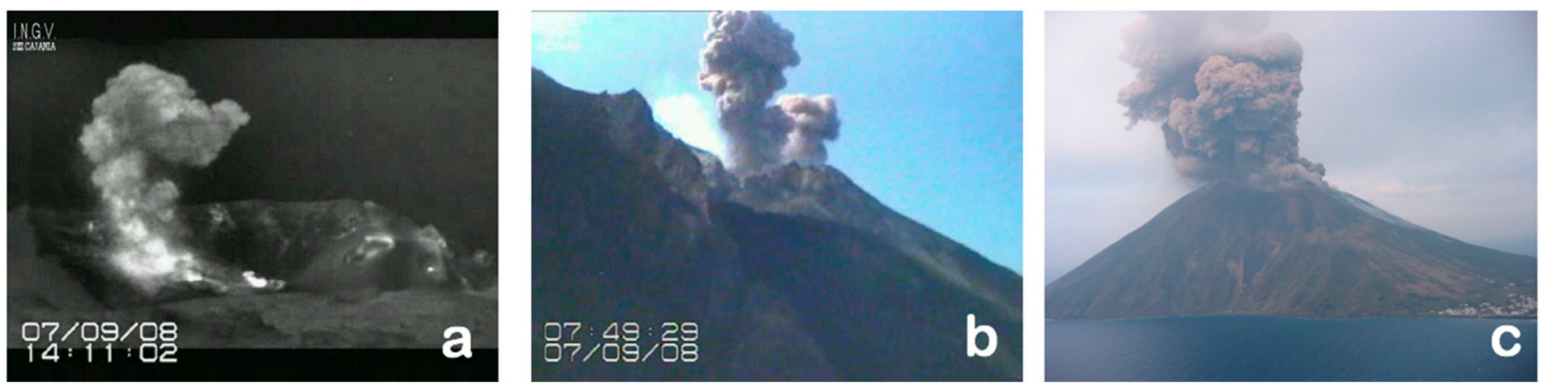

Figure 2. (a) Ordinary Strombolian explosion from the SWC producing an ash plume $\sim 80 \mathrm{~m}$ high, recorded by the SPI infrared camera located at Il Pizzo Sopra La Fossa on 7 September 2008, view from South. (b) Image from the SQV camera showing the eruptive ash column rising $\sim 300 \mathrm{~m}$ above the craters during the major explosion of 7 September 2008, view from NE. (c) Photo taken from helicopter by S. Calvari during the 5 April 2003 paroxysm, showing the eruptive column rising $>1 \mathrm{~km}$ above the summit of the volcano, view from South.

During paroxysms, and to a lower extent also during major explosions, a deep-seated, gas-rich and low porphyritic (LP) magma is erupted together with the gas-poor, high porphyritic (HP) magma residing in the upper conduit [28,36-39]. A common result of paroxysms is a deep modification of the crater area, with cinder cones and hornitos around vents being blown out and leaving a much wider and deeper crater depression [12,28-31,40,41]. Some paroxysms are associated with the emission of lava flows, and may occur both during $[29,30,42]$ or at the start of $[32,33]$ effusive eruptions, whereas others are not associated with lava effusion [12]. For those occurring during lava flow output, Calvari et al. [43] proposed calculating the daily erupted volume, suggesting that the drainage of degassed lava from the upper conduit could trigger the decompression and rise of the gas-rich LP magma from the source region causing the paroxysm. Paroxysms are often accompanied by the formation of hot avalanches or pyroclastic density currents (PDCs) spreading along the SdF slope and over the sea surface $[29,42,44,45]$, thus having the potential to impact not just the island, but also boats sailing close to the coast. More rarely, PDCs may affect the other slopes of the island, such as occurred after the 1930 and 1944 paroxysms [12,46]. PDCs are caused by the opening of flank fissures $[42,47,48]$, by the collapse of eruptive columns during paroxysms [41], by the collapse of small portions of the summit cone [49], by flank failure [50], or by the brecciation of lava flow fronts along the steep and incoherent SdF slope [29-31,42,44].

From a geophysical point of view, paroxysms (Figure 2c) at Stromboli share many common features with signals recorded during Vulcanian explosions $[29,51]$. They are associated with ultra-long-period (ULP) signals (having period $>100 \mathrm{~s}$ ) starting several 
seconds before and ending after the event [33]. In addition, they occur with a sharp signal in the borehole strainmeters revealing a strong overpressure build-up in the uppermost conduit by the LP gas-rich magma and moving from a source located at $1.4 \mathrm{~km}$ b.s.l. from seconds to minutes before the blast $[31,33,52]$. Conversely, major explosions (Figure $2 \mathrm{~b}$ ) are not associated with ULP signals, may involve little or none of the LP gas-rich magma [37,53], and have the source region located at $~ 500 \mathrm{~m}$ a.s.1., roughly in the same place as the persistent ordinary explosions (Figure 2a; [27,32]).

A first classification scheme that ranked eruption types qualitatively in order of increasing explosivity was proposed by Lacroix at the start of the twentieth century (reported by [54]). It distinguished four types of explosions: Hawaiian, Strombolian, Vulcanian, and Peléan. However, probably the first volcanological classification of explosive activity, based on collected data rather than on similarities with previous observations of key-type eruptions, was put forward by Walker in 1973 [55]. This was based on the extent and features of the resulting deposit, namely the dispersal area and the degree of fragmentation of the erupted material [55]. Following Walker [55], the most important features of an explosive eruption are its magnitude, which can be determined by estimating the volume of erupted ejecta, and the explosive violence or intensity, which depends on the eruption rate and affects the widespread of the products and their degree of fragmentation. In turn, the dispersal area is a function of the height reached by the eruptive column, thus the greater the height of the eruptive column, the wider the dispersal area [56], although the wind speed also influences the shape and extent of the final distribution of the ash particles $[43,57,58]$. The main problem with Walker's [55] classification is that it cannot be used for a rapid volcanic hazard assessment, given that the time needed to collect and interpret the volume, fragmentation degree and spread of the deposit is notable. The Walker [55] classification suggested that "Strombolian" activity can be defined by pyroclastic fall deposits with dispersal areas smaller than $10 \mathrm{~km}^{2}$ and a fragmentation index lower than $10 \%$ [59]. In addition, Walker's [55] classification does not sufficiently detail the scale of Strombolian activity, in order to allow distinguishing between persistent Strombolian explosions, major explosions or paroxysms. Newhall and Self [60] proposed using a Volcanic Explosivity Index (VEI) as a general indicator of the explosivity of an eruption, ranging from 0 (effusive) to 8 (highly destructive) on the basis of erupted volume, column height, and qualitative description of the power of the eruptive episode. However, Newhall and Self [60] rate Strombolian-type activity between VEI 1 and 2, and thus their classification is not appropriate to describe small differences like those observed at Stromboli. Houghton et al. [61] improved the VEI classification, extending the classification to negative values and expanding the limits of the Strombolian activity up to VEI -6. Barberi et al. [12] proposed a new classification just for Stromboli, defining "major explosions" as being those discrete explosions much more powerful than the persistent explosive activity and that cause fallout at Il Pizzo (Figures 1 and 2), 250 $\mathrm{m}$ away from the vents and where the tourists stop to watch the activity. Conversely, paroxysms are those impacting the settled areas, located $1.5 \mathrm{~km}$ beyond the craters. The main problem with Barberi's et al. [12] classification is that major explosions may or not impact the summit area of Il Pizzo as a result not of the explosion magnitude and intensity, but of the vents shape [27,62-64] and/or wind speed and direction (e.g., $[57,58]$ ).

A further distinction within "more intense than ordinary" explosions has been put forward by Andronico et al. [26]. The authors considered those explosions that have greater effects than ordinary Strombolian activity, but which at the same time cannot be classified as major explosions. Andronico et al. [26] suggested several criteria, based on measurements using the Istituto Nazionale di Geofisica e Vulcanologia (INGV) monitoring cameras, to define those events whose activity is intermediate between ordinary and major Strombolian activity: (1) larger-than-ordinary eruptive jets (>300 m) and dispersal area (>250 $\mathrm{m}$ around the vent; potentially reaching the area at Il Pizzo Sopra La Fossa, see Figure 1) of coarser erupted products (decimetre-sized blocks and bombs); (2) multiple 
vents involved ("explosion sequence" instead of "single burst"); (3) longer duration of the tephra ejection (>30 s).

A more recent classification, proposed by Houghton et al. [19], distinguishes the different Strombolian explosions, as well as the Hawaiian activity from the Strombolian one, by measuring the duration and height of the column of explosive events. They [19] made a distinction on the basis of a threshold duration of $300 \mathrm{~s}$, with sustained Hawaiian lava fountains displaying durations greater than $300 \mathrm{~s}$, and shorter events grouping all transient Strombolian explosions. The main limitation of this classification scheme is that it does not allow distinguishing between paroxysms, major explosions and persistent Strombolian activity at Stromboli, because these all fall below the $300 \mathrm{~s}$ threshold. This is why Houghton et al. [19] use an additional plot considering erupted mass (kg) together with duration (s), with several fields of mass eruption rates, from $1 \mathrm{~kg} / \mathrm{s}$ to $10^{8} \mathrm{~kg} / \mathrm{s}$.

A new approach, here proposed for the first time and tested on twelve events occurring at Stromboli since 25 June 2019, combines different geophysical monitoring and independent data in order to obtain a straightforward classification that can be used any time an explosion occurs. This classification scheme could be easily applied to other basaltic volcanoes, provided that a suitable monitoring network exists. In this paper, we describe the twelve explosive events on the basis of observations gathered from the INGV monitoring camera network, integrated with geophysical data from the INGV seismic network, as well as the ground deformations obtained from different remote sensing and geodetic techniques. These data, working at distinct sampling frequencies, allow analyzing the ground movements associated with different phenomena.

\section{Methods}

In the following, the data relative to each major explosion and paroxysms were derived from the INGV monitoring weekly bulletin, as specified, integrated by a more in-depth analysis of the images recorded by all INGV monitoring cameras. The starting time of each event is expressed in UTC, to make comparison easier with other geophysical data, and is obtained from the INGV monitoring cameras images, such as the duration of each event and the height of the eruptive column, intended as the maximum vertical extension of the ash plume, when within the field of view of the instruments. The position of the INGV monitoring cameras is shown in Figure 1, and their details are listed in Table 1. The time of each image is automatically attributed by the system using the Network Time Protocol [65]. Paroxysms produce much higher eruptive columns than the field of view of the INGV monitoring cameras (extending to a maximum of $750 \mathrm{~m}$ above the craters for SPCT, see Table 1), and in these three cases (3 July 2019, 28 August 2019, and 19 July 2020) we refer to published data. The maximum speed of ejecta or muzzle velocity is obtained from the analysis of the SQV camera images (Table 1), the only one that detected all the 12 explosive episodes considered here. The error on the vertical measurement is estimated at $9.5 \mathrm{~m}$. The resulting speed or muzzle velocity is averaged over $2 \mathrm{~s}$ of time lapse for each episode. The VLP size and other seismic signals are obtained from the INGV monitoring seismic network shown in Figure 1. The seismic network initially comprised 14 stations [66] and was deployed by INGV-Osservatorio Vesuviano (INGV-OV). From 2013, their number decreased because some sites became inaccessible both by land and by helicopter. The seismic stations are equipped with Guralp CMG 40T (60 s-50 Hz) velocimeters and Gilda data logger [67]. 
Table 1. List of the INGV monitoring cameras and of their main features. SdF = Sciara del Fuoco. The field of view is considered at the crater rim.

\begin{tabular}{|c|c|c|c|c|c|}
\hline Label & Type & Location & $\begin{array}{l}\text { Distance from the } \\
\text { Craters (m) }\end{array}$ & $\begin{array}{l}\text { Frame Rate } \\
\text { (hz) }\end{array}$ & $\begin{array}{l}\text { Field of View } \\
\text { (m) }\end{array}$ \\
\hline $\mathrm{SPT}$ & $\begin{array}{l}\text { Thermal } \\
\text { FLIR A310 }\end{array}$ & $\begin{array}{c}\text { Pizzo Sopra La Fossa } \\
890 \text { m a.s.l. }\end{array}$ & 250 & 2 & $500 \times 370$ \\
\hline SPCT & $\begin{array}{l}\text { Thermal } \\
\text { FLIR A320 }\end{array}$ & $\begin{array}{l}\text { West SdF flank } \\
85 \text { m a.s.l. }\end{array}$ & 1698 & 2 & $2150 \times 1613$ \\
\hline SCT & $\begin{array}{l}\text { Thermal } \\
\text { FLIR A655sc }\end{array}$ & $\begin{array}{l}\text { East SdF flank } \\
165 \mathrm{~m} \text { a.s.l. }\end{array}$ & 1538 & 2 & $807 \times 605$ \\
\hline SQT & $\begin{array}{l}\text { Thermal } \\
\text { FLIR A320 }\end{array}$ & $\begin{array}{c}\text { East SdF flank } \\
390 \text { m a.s.l. }\end{array}$ & 1027 & 0.5 & $455 \times 340$ \\
\hline SQV & $\begin{array}{c}\text { Visual } \\
\text { Sony FCB-EX480CP }\end{array}$ & East SdF flank, $390 \mathrm{~m}$ a.s.l. & 1027 & 0.5 & $657 \times 493$ \\
\hline SCV & $\begin{array}{c}\text { Visual } \\
\text { Mobotix M26 }\end{array}$ & $\begin{array}{l}\text { East SdF flank } \\
163 \mathrm{~m} \text { a.s.l. }\end{array}$ & 1538 & 2 & $1776 \times 1274$ \\
\hline
\end{tabular}

This study was also supported by the information from borehole geophysical instruments managed by INGV, in particular by the STDF tilt station and the SVO volumetric strainmeter station (Figure 1). The signals recorded at these two borehole stations are used in the official weekly reports produced by INGV to update the Italian Civil Protection Department and the local authorities on the eruptive state of the Stromboli volcanic island (http:/ / www.ct.ingv.it/index.php/monitoraggio-e-sorveglianza/prodottidel-monitoraggio/bollettini-settimanali-multidisciplinari (accessed on 9 February 2021)).

At Stromboli, the first shallow borehole tiltmeters were operating from 1992 by installing two stations with AGI 722 biaxial sensors with $10^{-7}$ rad precision at shallow depth of $\sim 3 \mathrm{~m}$ at Punta Labronzo in the northern flank and at Timpone del Fuoco (STDF) in the western flank (Figure 1), respectively [68]. In order to reduce the thermo-elastic noise affecting the shallow depth installations [69], STDF was installed in 2011 at $\sim 27 \mathrm{~m}$ below ground surface by using an AGI Lily sensor [70]. The data are collected with a sampling rate of 1 data/minute.

In order to improve the recording sensibility, two borehole strainmeters were installed at San Vincenzo Observatory (SVO) and at the Timpone del Fuoco (STDF) area in 2006 (Figure 1). These instruments, also called dilatometers, are Sacks-Everton types [71] which measure the volumetric strain with a nominal resolution up $10^{-11}$ in strain, depending on the final response of the coupling of the instruments with the surrounding rock. The devices were installed at a depth of $120 \mathrm{~m}$. The data are recorded and sampled at $50 \mathrm{~Hz}$ using a 24-bit digital recorder and are sent to INGV via TCP/IP [52,72]. The STDF strainmeter is unfortunately located in an unconsolidated medium causing a weak coupling and a low effective sensitivity, and moreover it suffered several signal interruptions. Instead, the SVO (Figure 1) is installed in massive rock providing a reliable signal with a sensitivity of $1 \times 10^{-11}$ per digital count [52].

Measuring surface deformation using the phase difference between two GBInSAR images enables recognising millimetre-scale displacements of the ground along the device line of sight (LOS) direction [73]. GBInSAR devices have the additional advantage of producing frequent SAR images (in the order of seconds to minutes), resulting in very high frequency deformation maps and time series [74]. Two GBInSAR devices are located in a stable area $\mathrm{N}$ of the SdF (Figure 1, Table 2). The GBInSAR devices are remote sensing imaging systems $[73,75,76]$ that emit and receive a burst of microwave pulses, repeating this operation while the sensor is moving [75] along a rail (track), that in the case of Stromboli is $4 \mathrm{~m}$ long [73]. The use of GBInSAR in the Ku-band (17-17.1 mm wavelength radar), can penetrate dust clouds (abundant especially during collapse events), and works in variable light and atmospheric conditions [49,77]. 
The GBInSAR measures the backscattered energy (amplitude) and the phase of the received radar signal. The latter can be used to estimate ground movements (along the LineOf-Sight, LOS) by using interferometric techniques. The interferograms are obtained from phase information of "averaged" images (i.e., by averaging the phase information derived from the different acquisitions, see Table 2 for averaging specification). Displacement cumulated maps are calculated using a staking algorithm to sum, pixel by pixel, the displacements for every consecutive pair of images, whereas displacement time series of selected points (averaged over 10 pixels) are obtained from cumulative displacement maps with a precision in the displacement measurement of $0.5 \mathrm{~mm}[73,74]$. Pixel resolutions are about $2 \mathrm{~m}$ in range, and $2 \mathrm{~m}$ on average in cross range, with a measurement precision referred to the displacement of less than $1 \mathrm{~mm}$ [78].

Table 2. Technical features of the two GBInSAR devices installed at Stromboli volcano.

\begin{tabular}{ccccccc}
\hline System & Model & Band & Revisiting Time [min] & $\begin{array}{c}\text { Averaging } \\
\text { Interval [min] }\end{array}$ & $\begin{array}{c}\text { Look Angle } \\
{[\text { deg] }}\end{array}$ & $\begin{array}{c}\text { Heading } \\
\text { Angle } \\
\text { [deg] }\end{array}$ \\
\hline $\begin{array}{c}\text { GBInSAR } \\
\text { NE400 * }\end{array}$ & $\begin{array}{c}\text { GBInSAR } \\
\text { LiSAmobile k09 }\end{array}$ & $\mathrm{Ku}$ & $\begin{array}{c}11 \text { (until November 2017) } \\
6 \text { (since November 2017) }\end{array}$ & 33 & $\begin{array}{c}\text { from } 63.8^{\circ} \\
\text { to } 90.0^{\circ}\end{array}$ & $\begin{array}{c}\text { from } 143^{\circ} \\
\text { to } 217^{\circ}\end{array}$ \\
\hline $\begin{array}{c}\text { GBInSAR } \\
\text { NE190 }\end{array}$ & $\begin{array}{c}\text { GBInSAR } \\
\text { LiSAmobile k09 }\end{array}$ & $\mathrm{Ku}$ & 2 & 30 & $\begin{array}{c}\text { from } 65.0^{\circ} \\
\text { to } 113.5^{\circ}\end{array}$ & $\begin{array}{c}\text { from } 115^{\circ} \\
\text { to } 245^{\circ}\end{array}$ \\
\hline
\end{tabular}

From ${ }^{*}$ Di Traglia et al. [74] and ${ }^{* *}$ Schaefer et al. [79].

\section{Results}

We describe here the 12 explosive events analysed in this paper on the basis of information gathered from the INGV weekly reports (Table 3) integrated with the analysis of the images recorded by the INGV monitoring webcams (Table 4). We then describe the seismic trace recorded for each explosive event, as well as the ground deformation recorded by the available instruments at different rate. Finally, we compare all these data together, listed in Table 4, to select the useful parameters that can be used for the Strombolian event classification at Stromboli volcano, and possibly for other basaltic volcanoes, provided that they have a suitable monitoring system.

Table 3. List of major explosions (ME) and paroxysms (PA) at Stromboli since 25 June 2019 and updated to 6 Dec 2020 . The date, time and features of the events are from the INGV weekly reports on the monitoring activity. NEC = NE crater zone; $\mathrm{CC}=$ central crater zone; $\mathrm{SWC}=\mathrm{SW}$ crater zone.

\begin{tabular}{|c|c|c|c|c|}
\hline Date & ME/PA & $\begin{array}{l}\text { Time } \\
\text { (UT) }\end{array}$ & Main Features & References and Notes \\
\hline 25 June 2019 & ME & 23:03:08 & CC crater zone widened after the explosive event. & $\begin{array}{l}\text { INGV weekly report } \\
27 / 2019^{1}\end{array}$ \\
\hline 3 July 2019 & PA & $14: 45: 43$ & $\begin{array}{l}\text { Lava flow within the crater. Blast starting from } \\
\text { SWC and NEC. The N rim of the crater terrace was } \\
\text { blown away. Two PDCs along the SdF and several } \\
\text { small lava flows. }\end{array}$ & $\begin{array}{l}\text { INGV weekly report } \\
28 / 2019^{1}\end{array}$ \\
\hline 13 July 2019 & ME & $20: 33$ & Intense event detected from seismicity. & $\begin{array}{l}\text { INGV weekly report } \\
29 / 2019^{1}\end{array}$ \\
\hline 15 July 2019 & ME & 19:09 & Intense event detected from seismicity. & $\begin{array}{l}\text { INGV weekly report } \\
29 / 2019^{1}\end{array}$ \\
\hline 28 August 2019 & PA & 10:17:20 & $\begin{array}{l}\text { Paroxysm comprising } 3 \text { pulses from SWC and NEC. } \\
\text { PDC along SdF, NEC crater rim eroded by the blast. }\end{array}$ & $\begin{array}{l}\text { INGV special report } \\
\quad 35 / 2019^{1}\end{array}$ \\
\hline 29 August 2019 & ME & 20:43:18 & $\begin{array}{l}\text { Two fountaining during lava flow output with } \\
\text { fallout on Ginostra. }\end{array}$ & $\begin{array}{l}\text { INGV daily report } n \text {. } \\
32,30 \text { August } 2019^{1}\end{array}$ \\
\hline
\end{tabular}


Table 3. Cont.

\begin{tabular}{|c|c|c|c|c|}
\hline Date & ME/PA & $\begin{array}{l}\text { Time } \\
\text { (UT) }\end{array}$ & Main Features & References and Notes \\
\hline 19 July 2020 & PA & $\begin{array}{l}03: 00: 42 \\
03: 01: 11 \\
03: 01: 28\end{array}$ & $\begin{array}{l}\text { Explosive sequence in } 3 \text { pulses from CC and SWC, } \\
\text { with fallout of bombs to Il Pizzo and down to } \\
500 \mathrm{~m} \text { asl. }\end{array}$ & $\begin{array}{l}\text { INGV weekly report } \\
30 / 2020^{1}\end{array}$ \\
\hline 13 August 2020 & ME & $14: 50: 28$ & Explosive sequence from SWC. No fallout. & $\begin{array}{l}\text { INGV weekly report } \\
\qquad 34 / 2020^{1}\end{array}$ \\
\hline 10 November 2020 & ME & $\begin{array}{l}20: 04: 21 \\
20: 04: 51\end{array}$ & $\begin{array}{l}\text { Explosive sequence from SWC followed by several } \\
\text { pulses at NEC and CC. }\end{array}$ & $\begin{array}{l}\text { INGV weekly report } \\
47 / 2020^{1}\end{array}$ \\
\hline 16 November 2020 & ME & 09:17:45 & $\begin{array}{l}\text { SWC, CC and NEC produced a blast expanding } \\
\text { horizontally like a rose. PDC along the SdF that spread } \\
\text { over the sea surface for } \sim 250 \mathrm{~m} \text {. Fallout at Il Pizzo. }\end{array}$ & $\begin{array}{l}\text { INGV weekly reports } \\
47 / 2020,48 / 2020^{1}\end{array}$ \\
\hline 21 November 2020 & ME & 00:33:17 & Sequence of 3 explosive events from NEC and CC. & $\begin{array}{l}\text { INGV weekly report } \\
48 / 2020^{1}\end{array}$ \\
\hline 6 December 2020 & ME & 05:12:44 & $\begin{array}{l}\text { Two pulses. Ballistics to } 300 \mathrm{~m} \text { height, ash plume, } \\
2 \text { PDCs along SdF. }\end{array}$ & $\begin{array}{l}\text { INGV weekly report } \\
50 / 2020^{1}\end{array}$ \\
\hline
\end{tabular}

1 The INGV monitoring reports can be found at http://www.ct.ingv.it/index.php/monitoraggio-e-sorveglianza/prodotti-delmonitoraggio/bollettini-settimanali-multidisciplinari (accessed on 9 February 2021).

\subsection{Explosive Events Description}

Table 3 shows a summary of the main features for each one of the explosive events analysed here, together with a preliminary classification of each episode taken by the INGV monitoring weekly reports. For each event, we display in Figures 3-14 a few thermal and visual frames extracted from the monitoring cameras, together with the seismic trace recorded by the IST3 INGV seismic stations (Z component, see Figure 1), in order to appreciate the size of the erupted ejecta and ash plume extension together with the seismic amplitude of the episode. Table 4 lists a number of parameters obtained for each of the explosive events from the analysis of available data.

\subsubsection{The 25 June 2019 Event}

The 25 June 2019 episode occurred at 23:03:08 from the CC vent of the crater area (Table 3, Figure 3a). It lasted $8 \mathrm{~s}$ (Table 4 ) and the erupted products spread laterally like a rose (Figure 3a) expanding mainly towards $\mathrm{W}$ and up to the crater rim. It caused a widening of the CC vent. The eruptive plume (Figure 3b) extended beyond the $\sim 250 \mathrm{~m}$ of the field of view (FOV) of the SQT camera and reached $\sim 500 \mathrm{~m}$, as detected from SQV. The seismic trace recorded during the event is shown in Figure 3c. The maximum speed of the ejecta (Table 4, $54.41 \mathrm{~m} \mathrm{~s}^{-1}$ ) was normally recorded at the start of the event and close to the vent, and rapidly declining upwards.
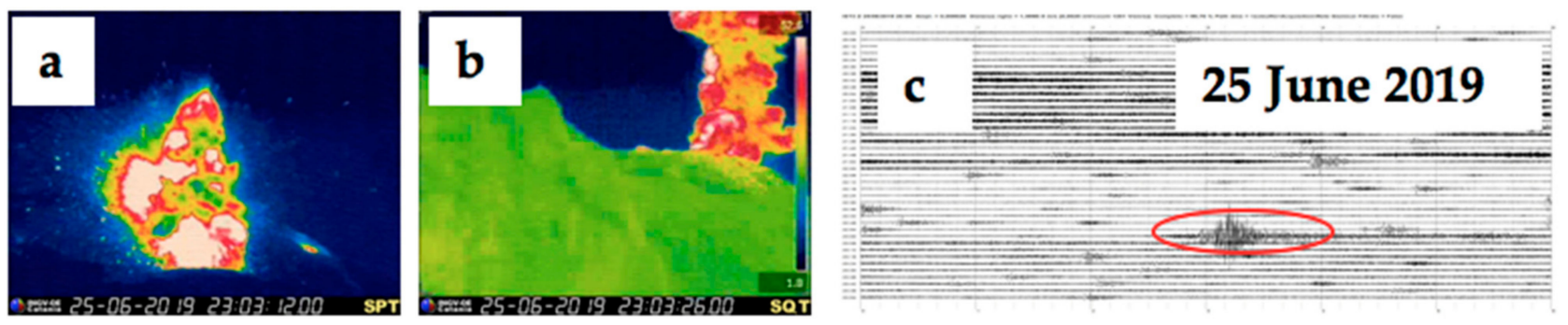

Figure 3. (a) Thermal image from the SPT camera of the CC vent with the start of the explosion on 25 June 2019 at 23:03:1200, view from S. Blue is cold, white is hot. (b) Thermal image from the SQT camera showing the eruptive plume at 23:03:2600, view from NE. Blue is cold, white is hot. (c) Seismic trace of the explosive event as recorded from the IST3 seismic station, Z component, with the red oval marking the explosive event here considered. See Figure 1 for station locations. 


\subsubsection{The 3 July 2019 Paroxysm}

The 3 July episode (Figure 4) was preceded by a significant increase in the intensity of explosive activity at all the summit vents. At 13:59 a strong explosion from the SWC was followed by lava flow output along the upper part of the Sciara del Fuoco (SdF). Images of the SQT camera show a small vent opening at the base of NEC, widening and feeding a lava flow that started spreading along the SdF from 14:02:40. Several lava flows from this vent overlapped the previous flux, spreading downslope. In the meantime, at 14:43:10 another small lava flow started from the CC crater, slowly spreading $S$ within the crater terrace (Figure $4 a-d$ ), followed by flows from the two NEC vents, and eventually joining with another flow erupted from the SWC vent. The maximum velocity of the jet, estimated at $101.92 \mathrm{~m} \mathrm{~s}^{-1}$ (Table 4), was recorded after $6 \mathrm{~s}$ of gradual increase due to the initial horizontal expansion of the jet. The main phase of the paroxysm involved the whole crater area. The column collapse produced two pyroclastic flows spreading NW along the SdF and over the sea surface for several hundred meters, and caused a significant widening of the crater terrace. The duration of the event, estimated on the basis of the images recorded by the monitoring cameras, is more than $2 \mathrm{~min}$ (Table 4). The end is difficult to estimate due to fallout and the ash cloud spreading for several minutes and limiting visibility from all cameras. Giordano and De Astis [41] estimated a maximum height of the eruptive column to $8.4 \mathrm{~km}$ above the crater (Table 4 ).
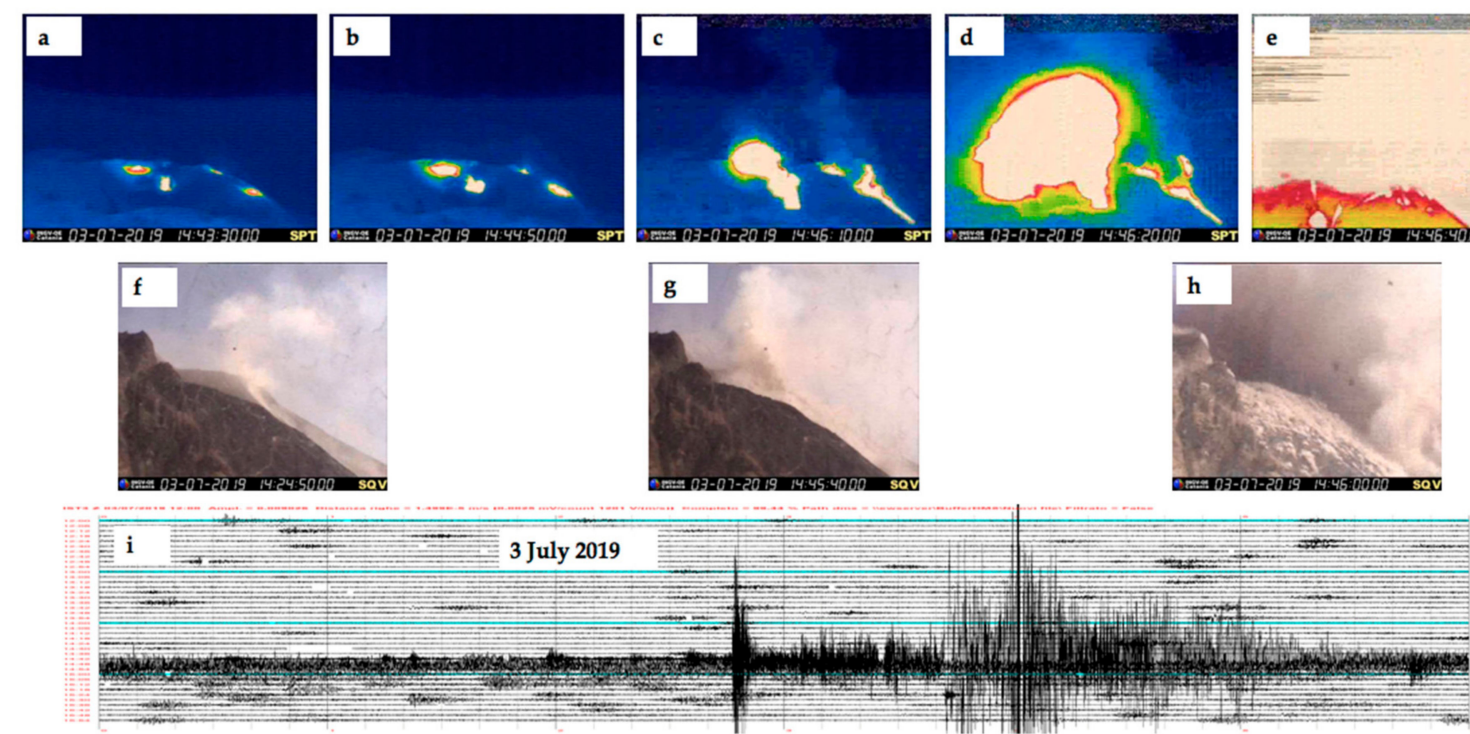

Figure 4. (a-e) Thermal images from the SPT camera showing the summit vents on 3 July 2019 at 14:43:3000 (a), at 14:44:5000 (b), at 14:46:1000 (c), at 14:46:2000 (d) and at 14:46:4000 (e), with (a-c) the emission of the intracrater lava flow from the CC vent and (d,e) the start of the jet explosion, view from S. Blue is cold, white is hot. (f-h) Visual images from the SQV camera showing (f) at 14:24:5000 the ash along the upper Sciara del Fuoco due to the lava flow output from the NEC, (g) at 14:45:4000 the eruptive plume, and (h) the fallout of bombs at 14:46:0000 along the upper Sciara del Fuoco, view from NE. (i) Seismic trace of the explosive event as recorded from the IST3 seismic station, Z component. See Figure 1 for station locations.

\subsubsection{The 13 July 2019 Event}

This strong explosion occurred while lava was flowing along the SdF slope erupted from the SWC and NEC vents [33,80,81]. This explosive event (Figure 5a,b) was considered stronger than the persistent activity just on the basis of the seismic trace, as shown in Figure $5 c$. 

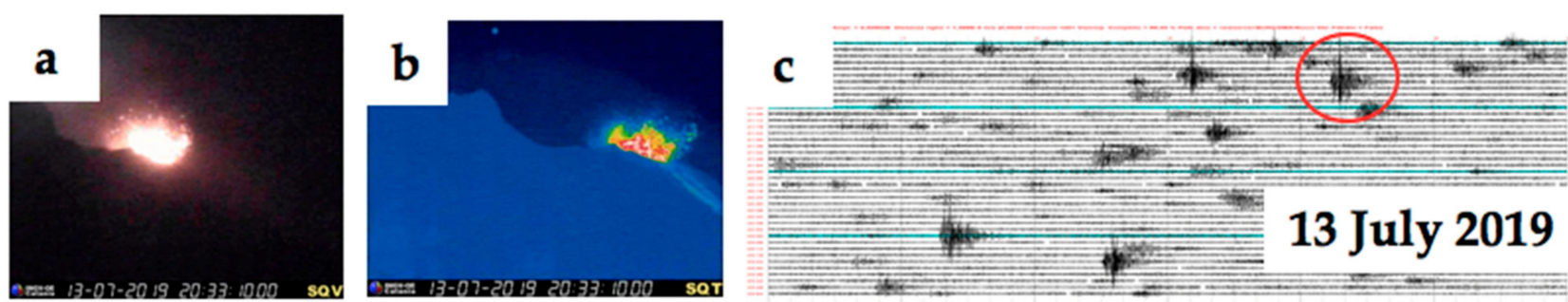

Figure 5. (a) Visual image from the SQV camera of the 13 July 2019 event at 20:33:10, view from NE with (b) corresponding thermal image taken from the SQT camera at 20:33:10. Blue is cold, white is hot. (c) Seismic trace with the red circle evidencing the explosive event displayed in the images above. See Figure 1 for station locations.

\subsubsection{The 15 July 2019 Event}

This explosion was considered stronger than the persistent ordinary explosive activity on the basis of the seismic trace. It occurred while lava flows were being erupted along the SdF $[33,80,81]$. The peculiar aspect of this explosion occurring from the SWC is that it took the form of a lateral jet (Figure 6a) spreading and widening upwards up to an estimated elevation of $\sim 380 \mathrm{~m}$ (Figure $6 \mathrm{~b}$ and Table 4 ), with incandescent bombs falling on the upper Sdf and at Il Pizzo Sopra La Fossa (Figure 6c,f, red circles). Figure $6 \mathrm{~g}$ shows the seismic signal, slightly differing from the persistent Strombolian explosions occurring during the day.
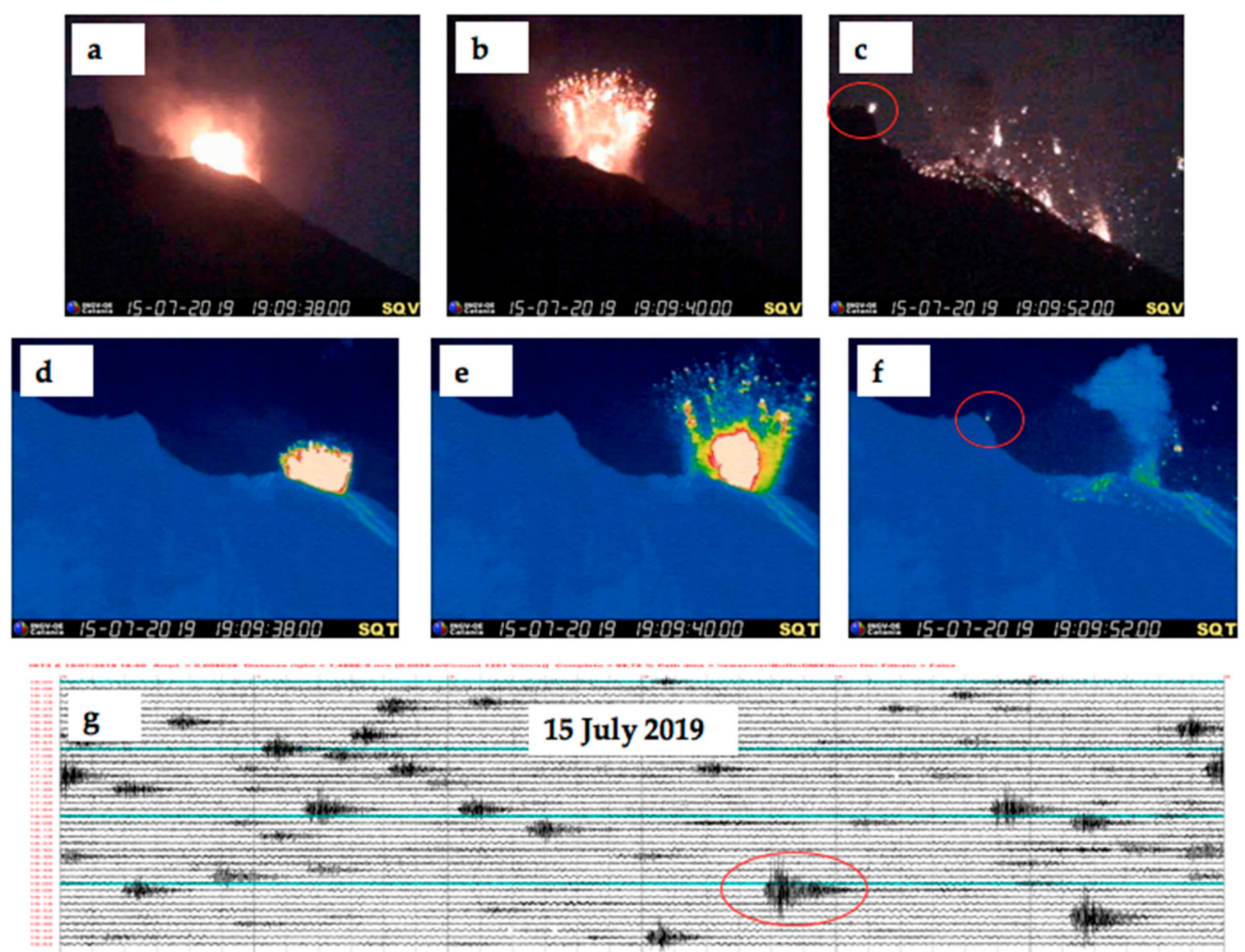

Figure 6. (a-c) Visual images from the SQV camera of the 15 July 2019 event at 19:09:38 (a), at 19:09:40 (b), and at 19:09:52 (c), view from NE. (d-f) Corresponding thermal images taken from the SQT camera, view from NE. Blue is cold, white is hot. The red circles in (c) and (f) indicate the incandescent block falling at Il Pizzo. (g) Seismic trace with the red ellipse evidencing the explosive event shown in the images above. See Figure 1 for station locations. 


\subsubsection{The 28 August 2019 Paroxysm}

The 28 August 2019 paroxysm (Figure 7) followed a day of increased explosive intensity at the summit craters of the volcano and occurred while the volcano was still the site of an effusive eruption from the summit craters [33,80,81]. At 10:17:20 an eruptive sequence started from the SWC portion of the crater terrace, giving rise to three pulses (Figure 7a-i), of which the first two from SWC and the last one, less intense from NEC, took the form of a lateral jet. The maximum velocity of the jet was $\sim 71.11 \mathrm{~m} \mathrm{~s}^{-1}$ (Table 4 ), and the duration of the event is almost $2 \mathrm{~min}$, with the end difficult to estimate due to fallout and ash cloud spreading for several minutes and obscuring sight from all cameras (Table 4). The eruptive column rose up to $4 \mathrm{~km}$ above the craters (INGV report, Table 4), or as much as $6.4 \mathrm{~km}$ ([41]; Table 4), and the fallout from the collapsing column produced two PDCs (Figure 7e) that spread along the $\mathrm{SdF}$ and over the sea surface for at least $540 \mathrm{~m}$ (Figure 7h). The explosion deeply modified the morphology of the crater area, widening the NEC towards NW. The seismic trace of the event is shown in Figure 7j.
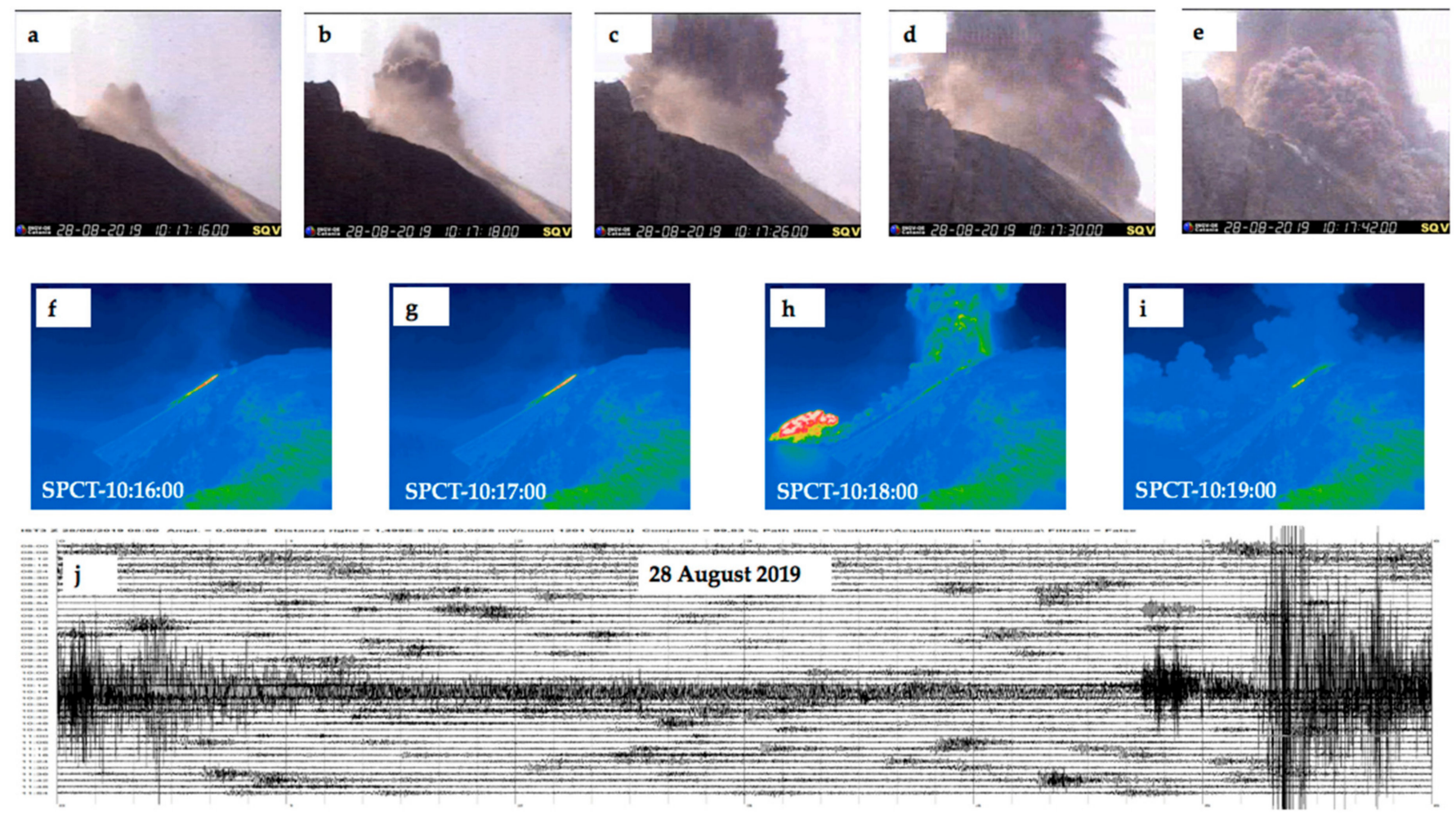

Figure 7. (a-e) Visual images from the SQV camera of the 28 August 2019 event recorded at 10:17:16 (a), 10:17:18 (b), 10:17:26 (c), 10:17:30 (d), and 10:17:42 (e), view from NE. (f,i) Thermal images from the SPCT camera, showing (f) the lava flow from the crater zone at 10:16:00 and at 10:17:00 (g), the eruptive column and PDC spreading over the sea surface for $\sim 300 \mathrm{~m}$ at 10:18:00 (h), and the ash cloud at 10:19:00 (i), view from W. Blue is cold, white is hot. (j) Seismic trace of the 28 August explosive paroxysm as recorded from the IST3 seismic station, $\mathrm{Z}$ component. See Figure 1 for station locations.

\subsubsection{The 29 August 2019 Event}

Two major explosive events occurred on this date, more or less with the same maximum elevation of the ejected spatter, which reached $\sim 350 \mathrm{~m}$ above the crater rim (Table 4 ). However, this activity was unusual, because it happened while lava was overflowing from the NEC crater rim, and because the volcanic tremor was extremely high for several hours, this activity resulting more as a continuous fountaining from SWC and CC rather than as single explosive Strombolian pulses. Figure 8 shows two frames recorded from the visible SQV camera, and the seismic trace as recorded by the IST3 seismic station. 

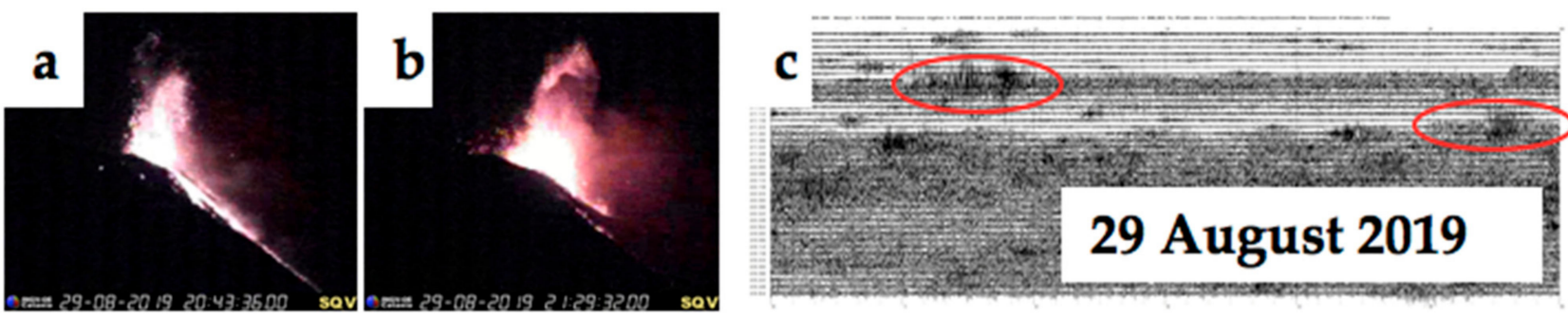

Figure 8. (a,b) Visual images from the SQV camera of the 29 August 2019 events recorded at 20:43:36 (a) and at 21:29:32 (b), view from NE. (c) Seismicity of 29 August 2019 as recorded from the IST3 seismic station, Z component. The two red ovals indicate the seismic trace corresponding to the two events shown above. See Figure 1 for station locations.

\subsubsection{The 19 July 2020 Paroxysmal Event}

This explosive event started at 03:00:42 from the CC (Figure 9a) and expanded to the SWC (Figure 9b), erupting most of the volume discharged during this event (Figure 9c). Another pulse occurred at 03:01:11 (Figure 9d) and a third pulse at 03:01:28, again from the SWC and displaying decreasing intensities, for a total explosive time of $58 \mathrm{~s}$ (Table 4). The maximum elevation of the ejecta, based on the images recorded by the SPCT camera, was more than $750 \mathrm{~m}$ above the crater rim (Figure 9k), but most of the fallout was spread horizontally all around the crater and up to the Pizzo Sopra La Fossa (Figure 9j, red circle). The fallout triggered several landslides along the SdF (Figure 9e-h), reaching the coast after $40 \mathrm{~s}$.
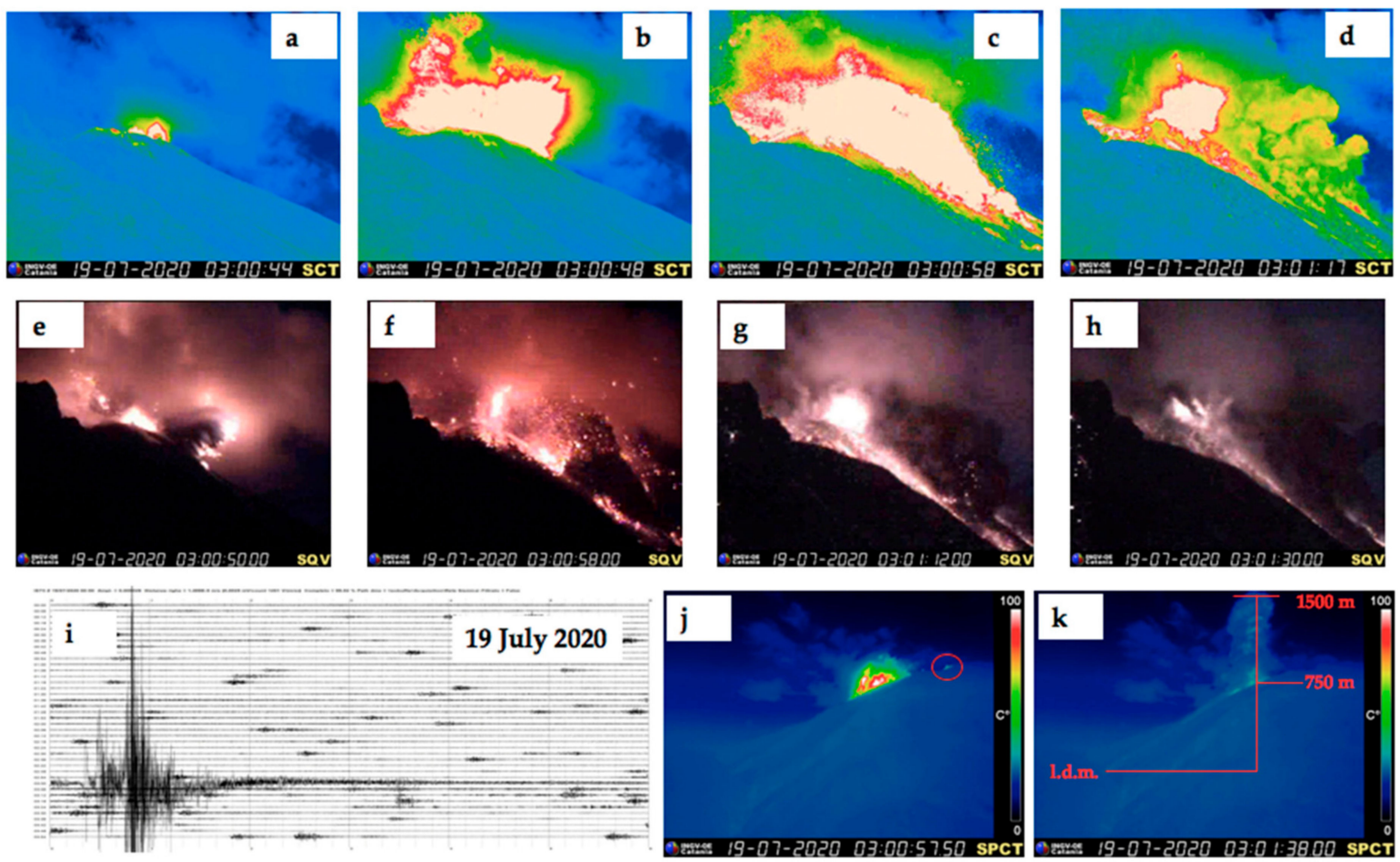

Figure 9. (a-d) Thermal images from the SCT camera of the 19 July 2020 explosive event at 03:00:44 (a), at 03:00:48 (b), at 03:00:58 (c), 03:01:17 (d), view from NE. Blue is cold, white is hot. (e-h) Visual images from the SQV camera recorded at 03:00:50 (e), at 03:00:58 (f), at 03:01:12 (g) and at 03:01:30 (h), view from NE. (i) Seismic trace of the 19 July 2020 paroxysm as recorded from the IST3 seismic station, $Z$ component. (j,k) Thermal images of the 19 July 2020 explosive event from the SPCT camera, view from W, showing (j) the fallout of bombs on the Il Pizzo Sopra La Fossa (indicated by the red circle) at 03:00:57.50, and (k) the vertical extent of the eruptive plume (750 $\mathrm{m}$ above the craters), recorded at 03:01:38. See Figure 1 for station locations. 


\subsubsection{The 13 August 2020 Event}

On 13 August at 14:50:27 (Figure 10), the SWC produced a stronger than average explosion, that from seismicity lasted about one minute and from the monitoring cameras $64 \mathrm{~s}$ (Table 4). It was characterized by a sequence of short events producing an ash plume that rose to $550 \mathrm{~m}$ above the craters (Table 4).
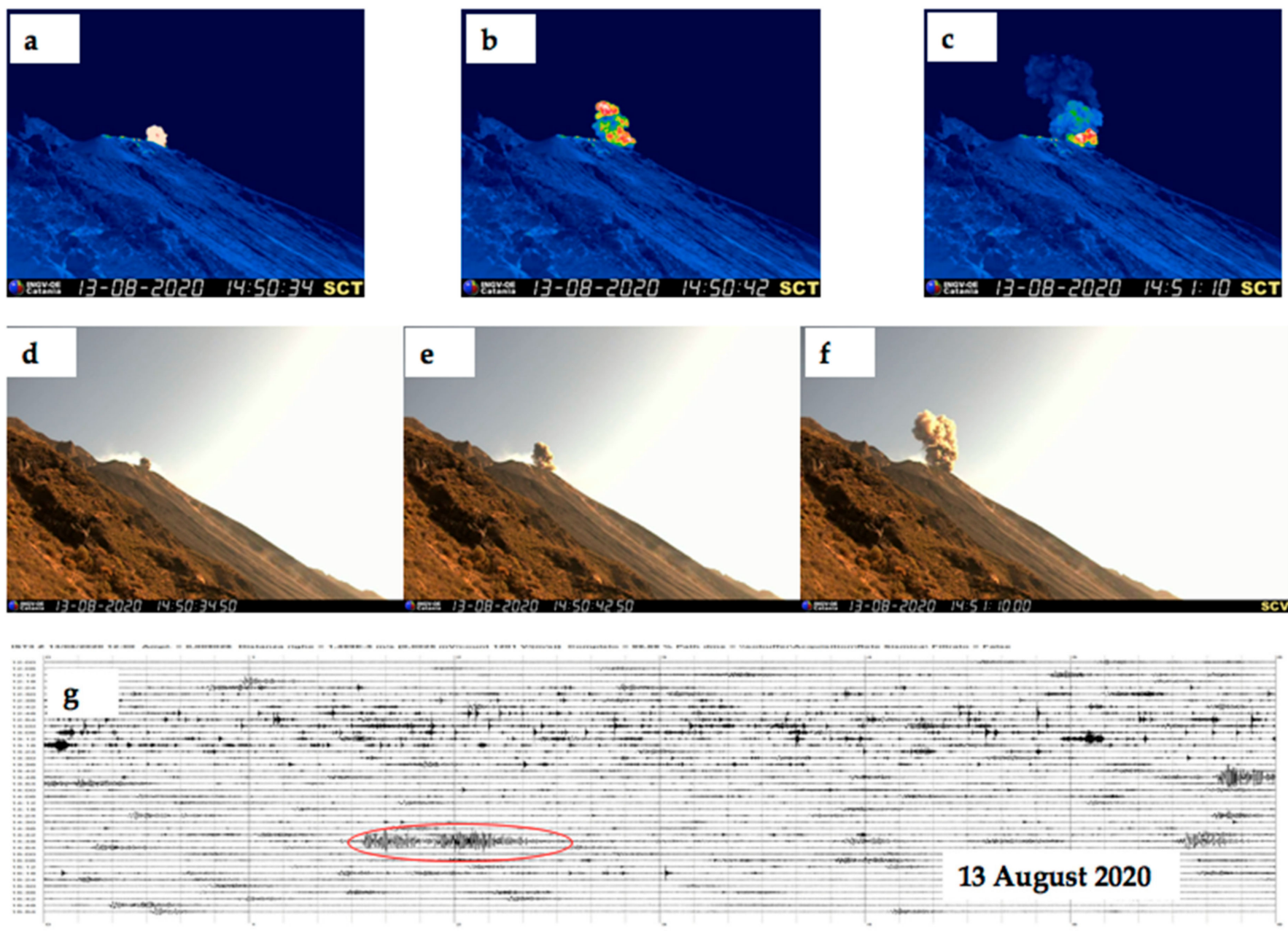

Figure 10. (a-c) Thermal images recorded from the SCT camera on 13 August 2020 at 14:50:34 (a), at 14:50:42 (b), and at 14:51:10 (c). Blue is cold, white is hot. View from NE. (d-f) Corresponding visual images from the SCV camera, view from NE, recorded at 14:50:3450 (d), at 14:50:4250 (e), and at 14:51:1000 (f). (g) Seismic trace of the explosive event as recorded from the IST3 seismic station, $\mathrm{Z}$ component. The red oval indicates the seismic trace corresponding to the event shown above. See Figure 1 for station locations.

\subsubsection{The 10 November 2020 Event}

The 10 November 2020 episode started from the SWC at 20:04:21 (Figure 11), forming an eruptive cloud reaching up to $600 \mathrm{~m}$ above the crater rim (Table 4). The explosive event then expanded to the NEC forming a jet expanding horizontally and causing a wide spatter fallout on the upper SdF, and eventually expanded to the CC producing a low fountaining with little or no fallout outside the crater. The duration of the first pulse was $20 \mathrm{~s}$, and the muzzle velocity of the ejecta was $54.50 \mathrm{~m} \mathrm{~s}^{-1}$ (Table 4). 

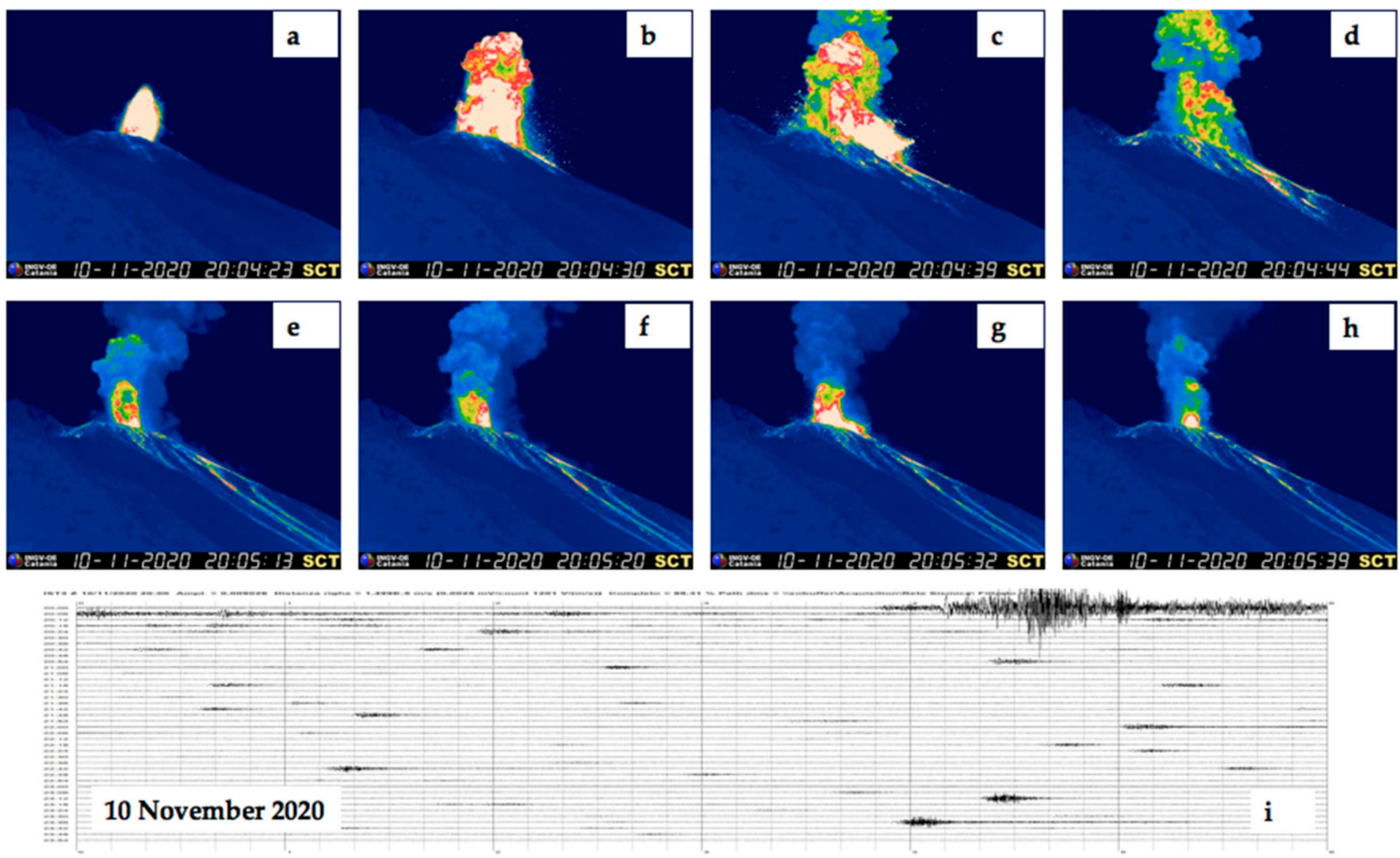

Figure 11. (a-c) Thermal images from the SCT camera recorded on 10 November 2020 at 20:04:23 (a), at 20:04:30 (b), at 20:04:39 (c), at 20:04:44 (d), at 20:05:13 (e), at 20:05:13 (f), at 20:05:32 (g) and at 20:05:39 (h), view from NE. Blue is cold, white is hot. (i) Seismic trace of the explosive episode, recorded by the IST3 station. See Figure 1 for station locations.

\subsubsection{The 16 November 2020 Event}

The 16 November 2020 episode was rather unusual, because of the clear ground deformation detected from the monitoring cameras and from the GBInSAR. The event started with puffing from the CC, followed by the fast propagation of a fracture from the CC to the SWC. This caused the upward tilting of the NE outer flank of the cone, forming two fractures on the NE flank and decompressing the uppermost conduit. This triggered a powerful explosion that started from the SWC (Figure 12). The explosion caused a blast spreading at first horizontally and, while the ash plume was still rising up, two pyroclastic density currents (PDCs) formed along the SdF, spreading down the slope and to the coast. The velocity of the PDC, obtained from the images of the SCT camera along the uppermost $250 \mathrm{~m}$ distance travelled along the $\mathrm{SdF}$, was estimated at $\sim 20 \mathrm{~m} \mathrm{~s}^{-1}$, which is in the range of the values obtained for the events occurring at Stromboli in March-April 2020 [44]. The PDC reached the coast after $42 \mathrm{~s}$, as detected from the SPCT camera, travelling the $1028 \mathrm{~m}$ of the slope at an average speed of $\sim 25 \mathrm{~m} \mathrm{~s}^{-1}$, and then expanded over the sea surface for about $250 \mathrm{~m}$. The event lasted $54 \mathrm{~s}$, and the ash plume observed from SPCT rose to about $690 \mathrm{~m}$ above the craters (Table 4). 

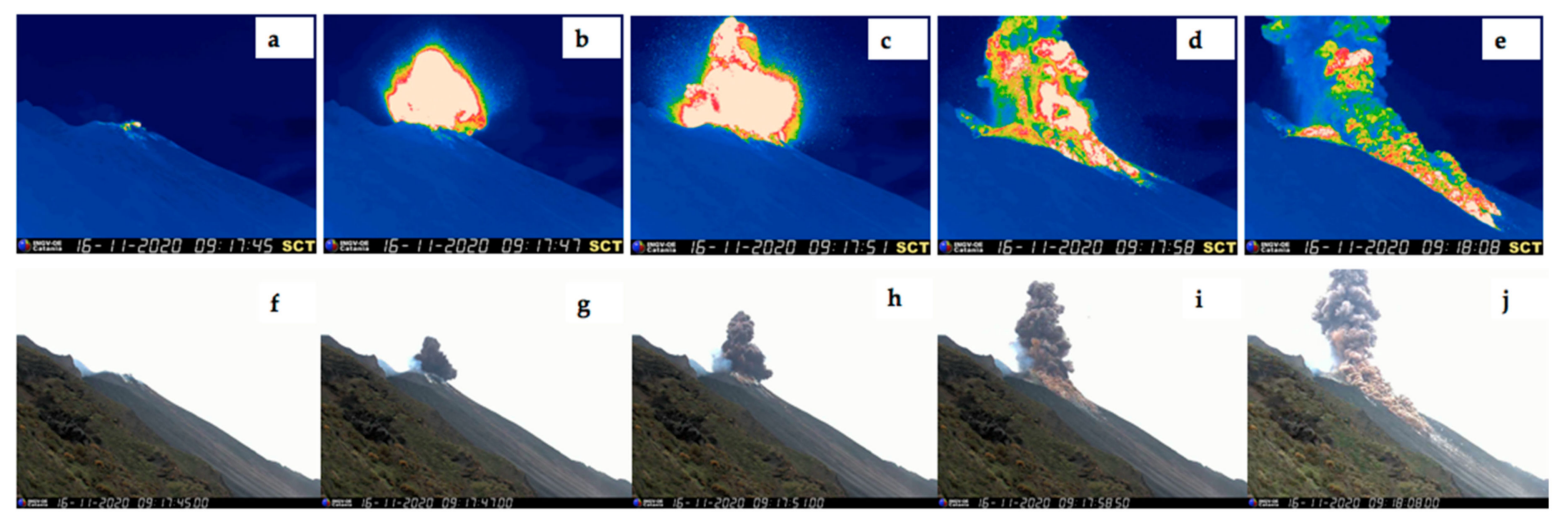

h is i
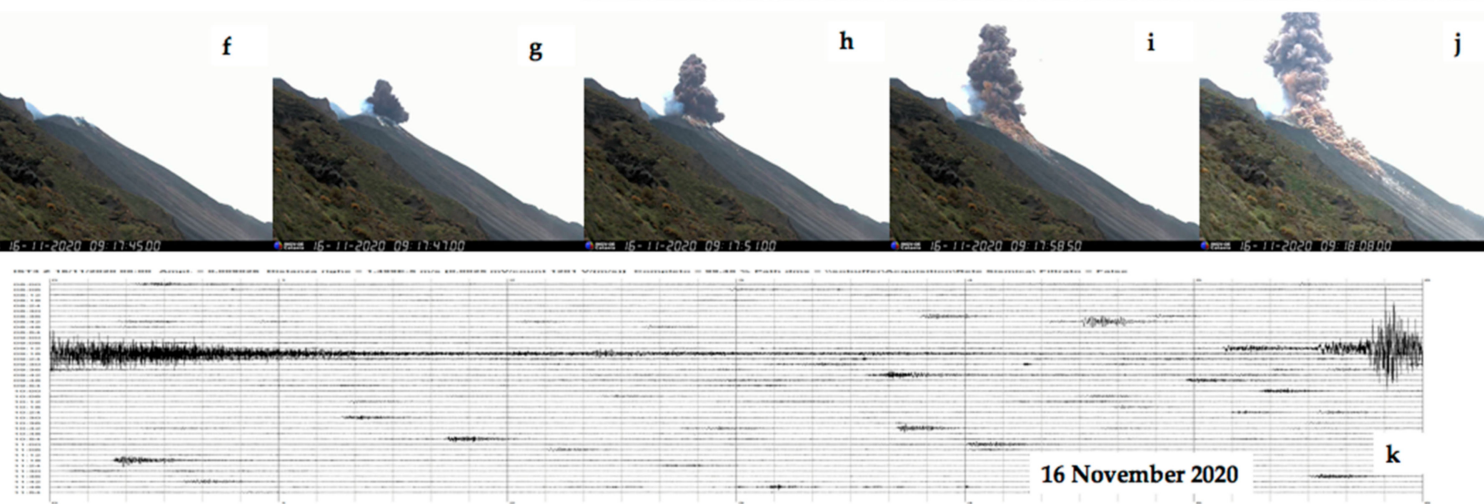

Figure 12. (a-e) Thermal images of the SCT camera recorded at 09:17:45 (a), 09:17:47 (b), 0917:51 (c), 09:17:58 (d), and 09:18:08 (e), and (f-j) corresponding visual images from the SQV camera of the 16 November 2020 event, view from NE. Blue is cold, white is hot. (k) Seismic trace of the event recorded by the IST3 station. See Figure 1 for station locations.

\subsubsection{The 21 November 2020 Event}

The 21 November 2020 occurred at 00:33 and was characterized by a sequence of three pulses of increasing intensity starting from the NEC and then expanding to the CC, lasting just $10 \mathrm{~s}$ (Figure 13). It was of very low intensity, producing an ash plume that reached $\sim 80 \mathrm{~m}$, with muzzle velocity of the ejecta of $9.48 \mathrm{~m} \mathrm{~s}^{-1}$ (Table 4).
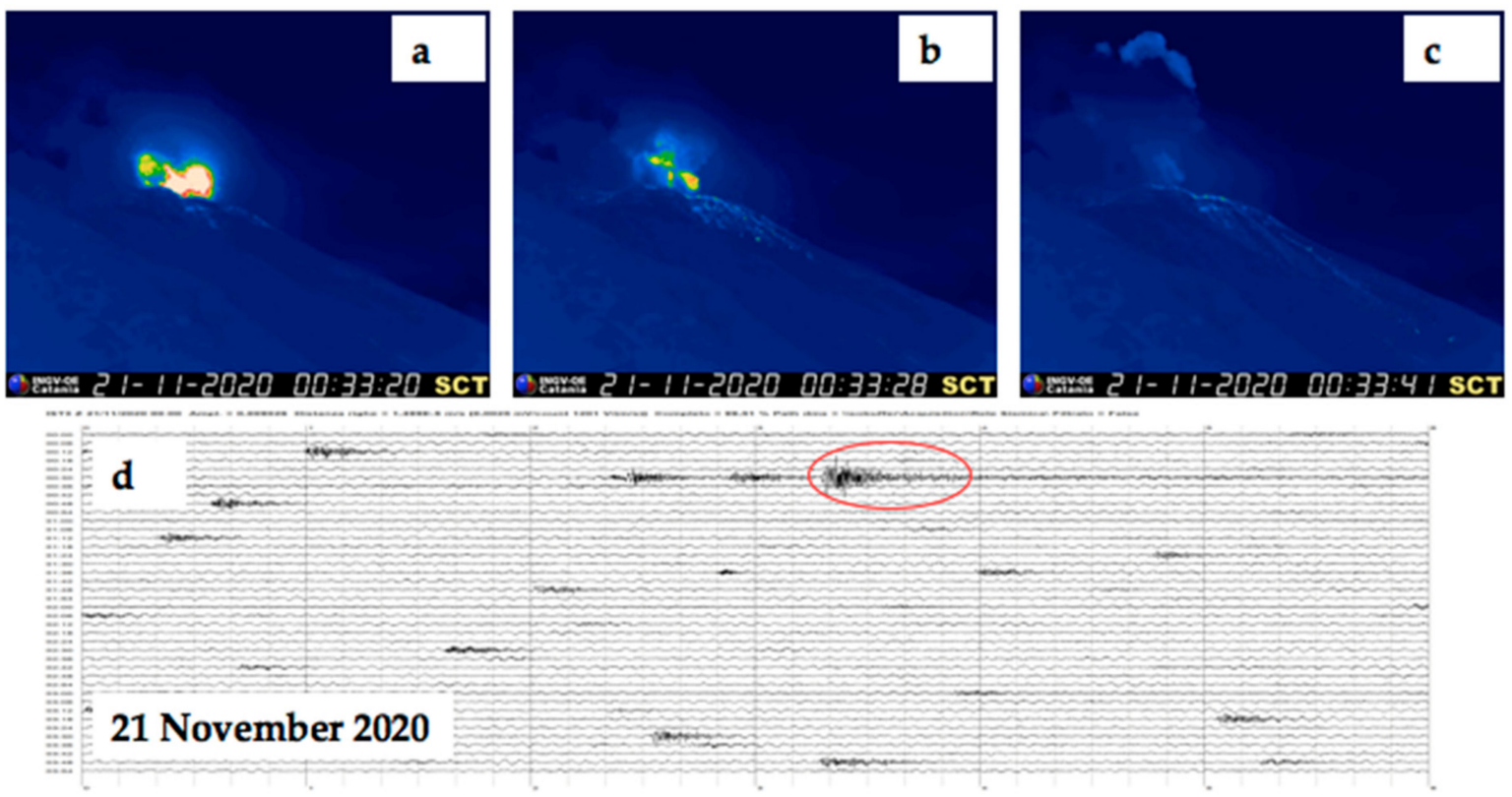

Figure 13. (a-c) Thermal images from the SCT camera of the 21 November 2020 event view from NE (blue is cold, white is hot), recorded at 00:33:20 (a), 00:33:28 (b), 00:33:41 (c) with (d) the corresponding seismic trace highlighted by the red oval. See Figure 1 for station locations. 


\subsubsection{The 6 December 2020 Event}

The 6 December 2020 episode (Figure 14) comprised two pulses occurring at 05:12:44 (Figure 14a-c) and 05:13:41 (Figure 14d), both starting from the SWC crater zone but also involving the CC crater zone (Figure 14b). The eruptive plume reached a maximum height of $300 \mathrm{~m}$ above the crater rim, and the fallout along the SdF triggered small PDC (Figure 14c,d). The seismic trace of this episode (Figure 14e) is so continuous to be more similar to a lava fountaining than to a Strombolian-type event.
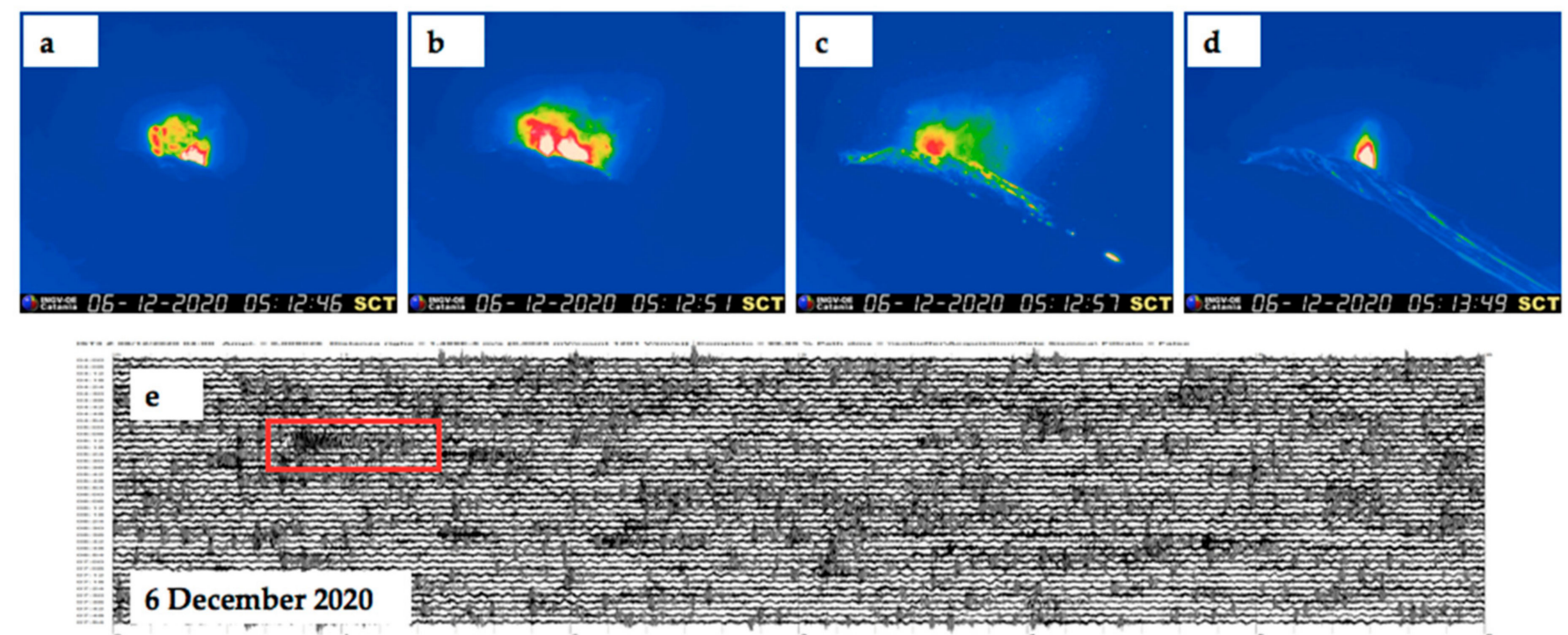

Figure 14. (a-d) Thermal images from the SCT camera of the 6 December 2020 event, view from NE, with (e) the corresponding seismic trace, indicated by the red box. In the thermal images blue is cold, white is hot.

The most important parameter to rate the magnitude and intensity of an explosion is the height of the eruptive column [82]. Other important volcanological parameters are the muzzle velocity and the duration of each explosive episode, which should be estimated using instruments that give comparable results. For this analysis, we have used the images of the SQV visual camera (see Figure 1 for camera location and Table 1 for camera features) which is the only one that recorded all the 12 eruptive events considered here. The results of muzzle velocities and explosion durations obtained from the analysis of the SQV images are reported in Table 4, together with the "V $\times \mathrm{D}$ parameter", obtained multiplying the muzzle velocity (in $\mathrm{m} \cdot \mathrm{s}^{-1}$ ) by the duration (expressed in seconds) for each event.

\subsection{VLP Size}

Seismic signals associated with the Stromboli explosions contain Very Long Period (VLP) pulses, typically in the $0.05-0.5 \mathrm{~Hz}$ frequency band, that are generated by the explosive mechanism [32,83-85]. These signals have a direct link with the eruptive process of both ordinary and major explosions. Components with an even longer period are recorded in the seismograms of paroxysmal explosions. Figure 15 shows the seismograms and spectrograms of paroxysmal (Figure 15a), major (Figure 15b) and ordinary (Figure 15c,d) explosion types. 

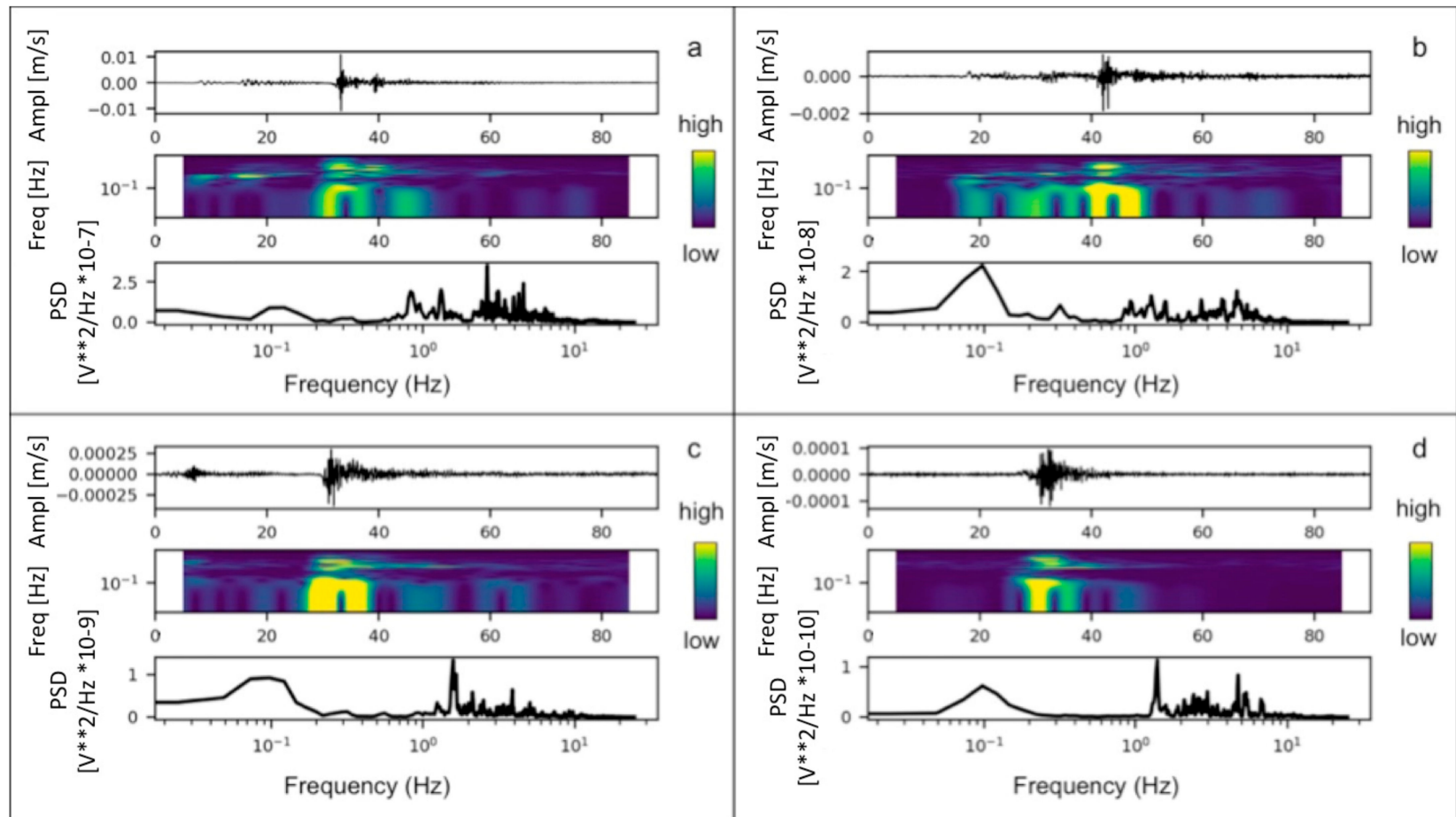

Figure 15. Seismograms (top), spectrograms (middle) and spectra (bottom) of four examples of explosions of different sizes. (a) The paroxysmal explosion of 19 July 2020 (03:00 UTC); (b) the major explosion on 10 November 2020 (20:04 UTC); (c) the explosion on 21 November 2020 (00:33 UTC); (d) an ordinary explosion on 19 July 2020 (02:54 UTC). In the horizontal axes of seismograms and spectrograms, time is expressed in seconds.

The signal amplitudes and the VLP events associated with the 12 explosions analysed in this article are very different (Figures 16 and 17).

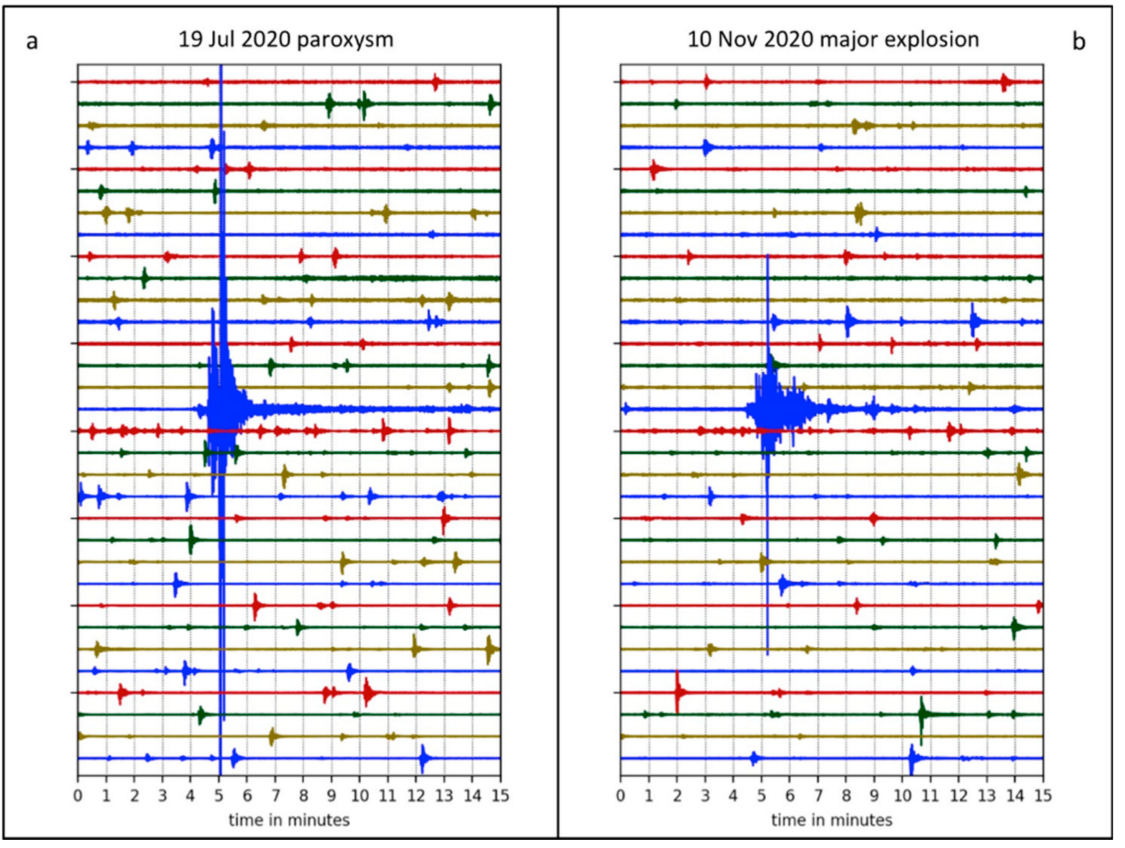

Figure 16. Comparison between the seismograms of a paroxysm (a, 19 July 2020) and a major explosion (b, 10 November 2020). Both plots (a and b) represent an 8-h signal recording of the east-west component of the STRA station (see Figure 1 for station location). The small amplitude transients that are recognizable in both plots are due to the ordinary Strombolian explosions. 

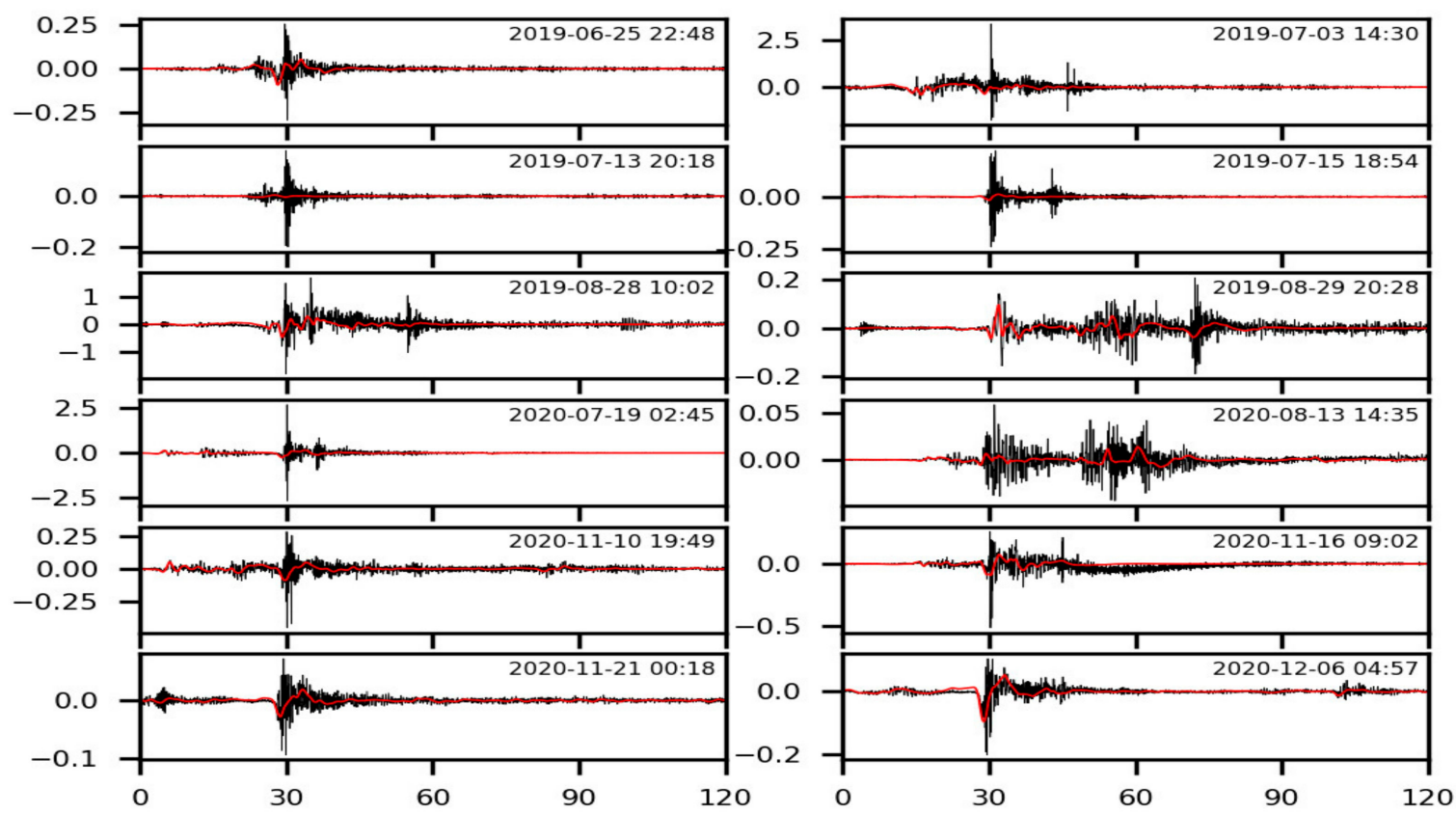

Figure 17. Seismograms of the 12 explosions, here considered as case studies, as recorded from station STRA, East component (see Figure 1 for station location). The red lines represent the filtered signal in the VLP frequency band $(0.05-0.5 \mathrm{~Hz})$. The vertical scale is expressed in $10^{6}$ counts. The filtered signal is scaled by a factor of 2 . The time on the horizontal axis is in seconds.

To represent the magnitude of the explosions through seismic measurements we use the VLP size introduced by Giudicepietro et al. [33]. This parameter is defined as the maximum value of the RSAM of a $30 \mathrm{~s}$ sliding window that moves in a 30-min time interval of signal, filtered in VLP frequency band $(0.05-0.5 \mathrm{~Hz})$. The $30-\mathrm{s}$ window moves by $1 \mathrm{~s}$ steps and produces 1770 RSAM values in a 30-min time interval of signal. The maximum of these values is the VLP size of that half hour signal [33]. This analysis typically returns 48 values per day representing the size of the largest VLP event for every half hour of the day. This parameter was used in Giudicepietro et al. [32] to highlight variations in the "magnitude" of the VLPs associated with ordinary Strombolian explosions in the period preceding the paroxysm of 3 July 2019, and therefore to discover a seismic precursor of the paroxysm. However, the VLP size, which is sensitive to the amplitude and duration of the greater amplitude portion of a VLP signal, is also suitable for providing the "magnitude" of the VLP seismic transients associated with explosions of greater energy than ordinary ones such as major explosions and paroxysms. Therefore, the VLP size gives the possibility to create a relative scale of the "magnitude" of the Stromboli explosions on the basis of the seismic signal associated with them. For each explosion reported in Table 1 we computed the VLP size in 24-h long time intervals ( $12 \mathrm{~h}$ before and $12 \mathrm{~h}$ after the explosion). For some intervals, the signals are missing; in that case the value of the VLP size is reported as zero, for example a few hours before the explosion of 6 December 2020 (Figure 18). We normalized the VLP size values (to 100,000) with respect to the maximum, which coincides with the paroxysmal explosion of 3 July 2019. The VLP size of the 12 explosions listed in Table 3 are reported in Table 4, where they are compared with other parameters extracted from the analysis of the camera images and from the str in and tilt. 


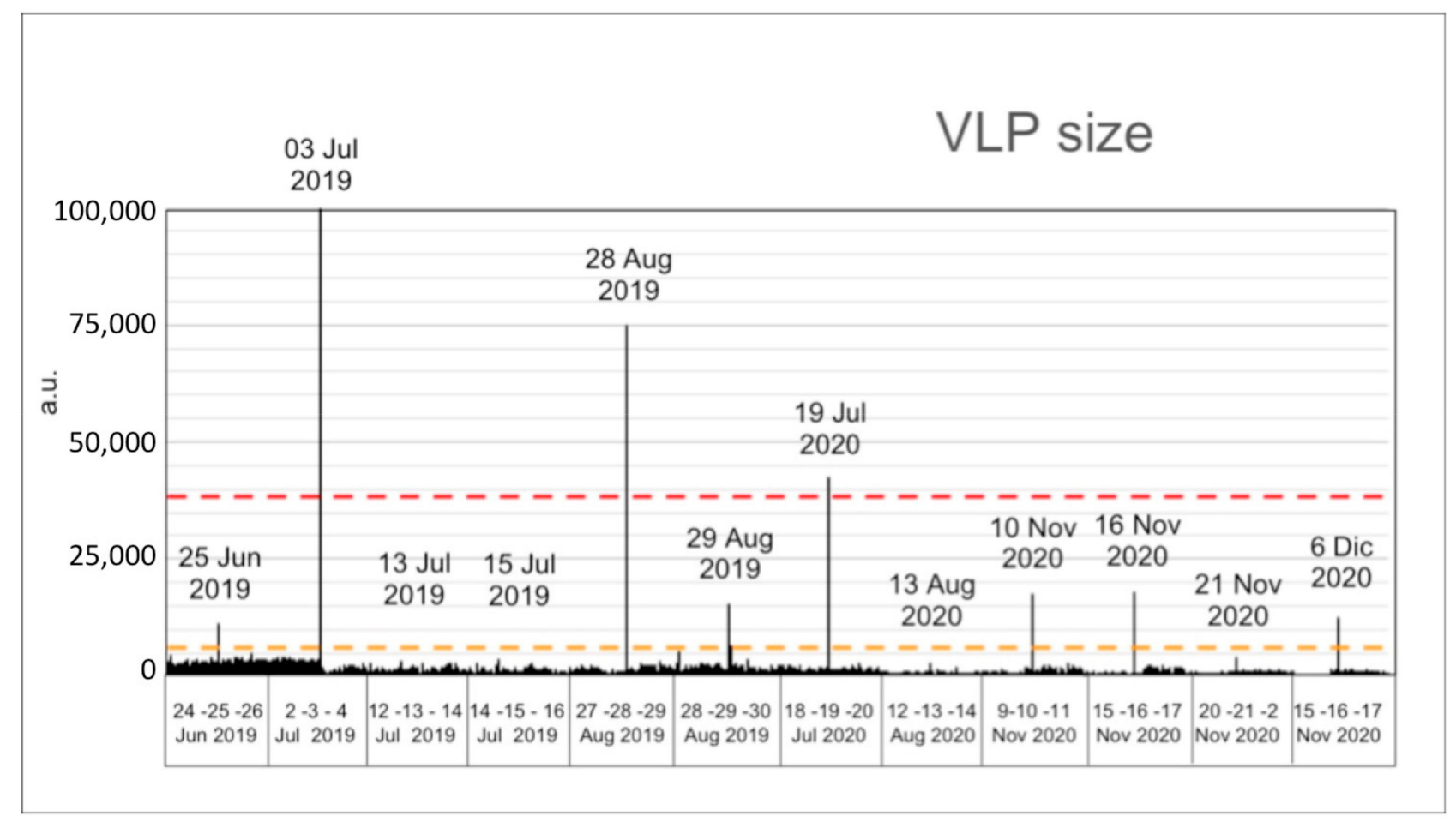

Figure 18. VLP size calculated in twelve 24-h intervals, each containing one of the twelve explosions selected as case studies. The histogram is normalized to 100,000 in arbitrary units (a.u.). The dashed orange line indicates the VLP size threshold, which separates the ordinary from the major explosions. The red dashed line indicates a possible VLP size threshold to separate major explosions from paroxysms (3 July 2019, 28 August 2019 and 19 July 2020). Note that this is not a time series in the whole considered period, but is representative only of the days reported in the abscissa axis. In this way, it is possible to observe how the VLP size of the most energetic explosive event far exceeds the VLP size of the "ordinary" explosions that occurred in the $24 \mathrm{~h}$ around it.

In order to approach the problem of classifying Stromboli explosions using the normalized VLP size, we chose two thresholds that separate the field of ordinary explosions from that of major ones, and the field of major explosions from paroxysms. The two thresholds are shown in Figure 18 as two dashed horizontal lines, orange and red, respectively.

The first threshold (ordinary versus major explosions) was obtained by adding $10 \%$ to the maximum value of VLP size of the ordinary explosions that fall within the analysed dataset (twelve 24-h long time intervals). Its value is 6,136 and is indicated by a horizontal dashed orange line in Figure 18. The second threshold was obtained by subtracting 10\% from the VLP size of the smallest paroxysm considered among the case studies of our dataset, which is the 19 July 2020 event. The VLP size for this episode is 38,395. Applying this criterion to define the limits of the VLP size relative to ordinary, major and paroxysmal explosions, the events of 13 July 2019, 15 July 2019, 13 August 2020 and 21 November 2020 fall into the field of the ordinary explosions. This happens because their VLP size is smaller than that of the ordinary explosions recorded in other periods, for example when compared to the ordinary explosions that preceded the paroxysm of 3 July 2019 (Figure 18). The aforementioned explosions were classified as major as they are slightly larger than those on the day they occurred; therefore, they represented relative outliers.

This type of analysis, extended to longer periods, offers a fast and reliable way to define a relative quantitative scale of Stromboli explosion magnitude and can provide a criterion for the traditional distinction between ordinary, major and paroxysmal explosions which is historically linked to scenarios of possible impact on the island [12]. 


\subsection{Borehole Geophysical Instruments (Tilt and Strain)}

At Stromboli, the tiltmeters recorded signal changes during middle-term processes such as the attempt of a dike intrusion during the first months of 1995 [68] and the volcano deflation associated with the 2007 effusive eruption [86]. On the contrary, also due to the low sampling rate (1 data/minute), it is more difficult to detect clear changes associated with the impulsive and short-time events such as the explosions. However, even with few samples recorded during the explosive events, STDF can record small transient changes of short duration during the major explosions and the paroxysms (i.e., tilt variations in a few samples during the few minutes accompanying the explosion). Giudicepietro et al. [32] focused on the 1 December 2017 major explosion as a case study, and also reported the tilt data showing a very small variation of $\sim 0.5 \times 10^{-7}$ rad during the explosion. In the 20192020 interval considered in this study, STDF recorded tilt variations of similar magnitude during the major explosions occurring during the 10 and 16 Nov 2020 events, while no detectable tilt change was recorded for the other major explosions (Table 4). A further interesting aspect is that during the paroxysms of 3 July 2019 and 19 July 2020 (for the 28 August 2019 paroxysm, the station was out of order) the STDF tilt showed a bigger short-term transient of $0.5 \times 10^{-6} \mathrm{rad}$ (Table 4 ).

Table 4. Multi-parametric measurements of the 12 explosions considered as case studies useful for their classification. The duration of each event and its muzzle velocity are obtained from the SQV camera monitoring videos. Plume height $(\mathrm{H})$ is considered above crater rim and measured from the fixed monitoring cameras or reported (where specified) from references. See text for further explanations.

\begin{tabular}{|c|c|c|c|c|c|c|c|}
\hline $\begin{array}{l}\text { Date } \\
\text { Time } \\
\text { (UT) }\end{array}$ & $\begin{array}{l}\text { Muzzle } \\
\text { Velocity } \\
\left(\mathrm{m} \mathrm{s}^{-1}\right)\end{array}$ & $\begin{array}{l}\text { Plume H } \\
\text { (m) }\end{array}$ & $\begin{array}{l}\text { Duration } \\
\quad \text { (s) }\end{array}$ & $\begin{array}{c}\text { VD } \\
\text { Parameter }\end{array}$ & $\begin{array}{l}\text { VLP Size } \\
\text { (Normalized } \\
\text { Counts) }\end{array}$ & $\begin{array}{l}\text { Strain SVO } \\
\text { (Counts) }\end{array}$ & $\begin{array}{c}\text { Tilt } \\
\text { STDF }[x ; y] \\
\text { (Micro-Strain) }\end{array}$ \\
\hline $\begin{array}{l}25 \text { June } 2019 \\
\text { 23:03:08 }\end{array}$ & 54.41 & $\sim 500$ & 8 & 435 & 11,276 & $\sim 600^{1}$ & 0,0 \\
\hline $\begin{array}{l}3 \text { July } 2019 \\
14: 45: 43\end{array}$ & 101.92 & $8400^{2}$ & 160 & 16,307 & 100,000 & $\sim 8000^{1}$ & $\sim 0.4 ; \sim 0.45$ \\
\hline $\begin{array}{c}13 \text { July } 2019 \\
20: 33\end{array}$ & 29.63 & 110 & 12 & 356 & 3377 & $0^{1}$ & $0 ; 0$ \\
\hline $\begin{array}{c}15 \text { July } 2019 \\
19: 09\end{array}$ & 61.63 & 380 & 18 & 1109 & 3909 & $0^{1}$ & $0 ; 0$ \\
\hline $\begin{array}{c}28 \text { August } 2019 \\
10: 17: 20\end{array}$ & 71.11 & $\begin{array}{l}4000^{1} \\
6400^{2}\end{array}$ & 154 & 10,951 & 75,110 & $\sim 8000^{1}$ & No data \\
\hline $\begin{array}{c}29 \text { August } 2019 \\
\text { 20:43:18 }\end{array}$ & 35.55 & 350 & 38 & 1351 & 15,437 & $\sim 500^{1}$ & No data \\
\hline $\begin{array}{c}19 \text { July } 2020 \\
\text { 03:00:42 }\end{array}$ & 78.22 & $>750$ & 58 & 4537 & 42,661 & $\sim 2000^{1}$ & $\sim 0.4 ; \sim 0.05$ \\
\hline $\begin{array}{c}13 \text { August } 2020 \\
\text { 14:50:27 }\end{array}$ & 11.86 & 550 & 64 & 759 & 2866 & $0^{1}$ & $0 ; 0$ \\
\hline $\begin{array}{c}10 \text { November } 2020 \\
20: 04: 21\end{array}$ & 54.50 & 600 & 20 & 1090 & 17,688 & $\sim 300^{1}$ & $\sim 0.05 ; \sim 0.03$ \\
\hline $\begin{array}{c}16 \text { November } 2020 \\
09: 17: 45\end{array}$ & 54.51 & $1000^{1}$ & 54 & 2944 & 18,006 & $\sim 300^{1}$ & $\sim 0.05 ; \sim 0.04$ \\
\hline $\begin{array}{c}21 \text { November } 2020 \\
\text { 00:33:17 }\end{array}$ & 9.48 & 80 & 10 & 95 & 4029 & $0^{1}$ & $0 ; 0$ \\
\hline $\begin{array}{c}6 \text { December } 2020 \\
\text { 05:12:44 }\end{array}$ & 11.52 & 300 & 8 & 92 & 12,778 & $0^{1}$ & $0 ; 0$ \\
\hline
\end{tabular}

\footnotetext{
${ }^{1}$ The INGV monitoring reports can be found at www.ct.ingv.it. ${ }^{2}$ Giordano \& De Astis [41].
} 
The SVO strainmeter, thanks to its high precision and to the high frequency sampling rate $(50 \mathrm{~Hz})$, is a powerful tool to detect transient changes associated with the explosive activity. These changes are extremely clear for the paroxysms, for which the instrument was able to detect signal variations both preceding these events by $10 \mathrm{~min}$ and accompanying the explosive phase [31,52]. At SVO, the positive change (with positive change measuring compression in the rock surrounding the sensor) that preceded the explosive events by a few minutes ranged from $\sim 8000$ counts for the 3 July and 28 August 2019 events, to no change for the other smaller events. In Table 4 , we report the positive strain change cumulated before the explosion as shown by the INGV weekly reports.

\subsection{GBInSAR}

The GBInSAR devices measured ground displacement associated with four events (Table 4): on 3 July 2019, 29 July 2019, 19 July 2020, and 10 November 2020, even though the behaviour was very different, suggesting different mechanisms and sources of deformation. The 3 July 2019 paroxysm was the only event to be preceded by a clear ground deformation detected from GBInSAR, consistent with an inflation of the summit crater terrace, which began about two and a half hours before, and which progressed until the explosion. Inflation was observed in the interferogram between 10:34 UTC and 12:13 UTC (displacement rate: $4.4 \mathrm{~mm} / \mathrm{h}$; Figure 19a), progressed in the successive interferograms (Figure 19b,c), reaching the maximum value of $44.2 \mathrm{~mm} / \mathrm{h} 2 \mathrm{~min}$ before the explosion (interferogram between 14:36 UTC and 14:43 UTC (displacement rate: $42.2 \mathrm{~mm} / \mathrm{h}$; Figure 19d).
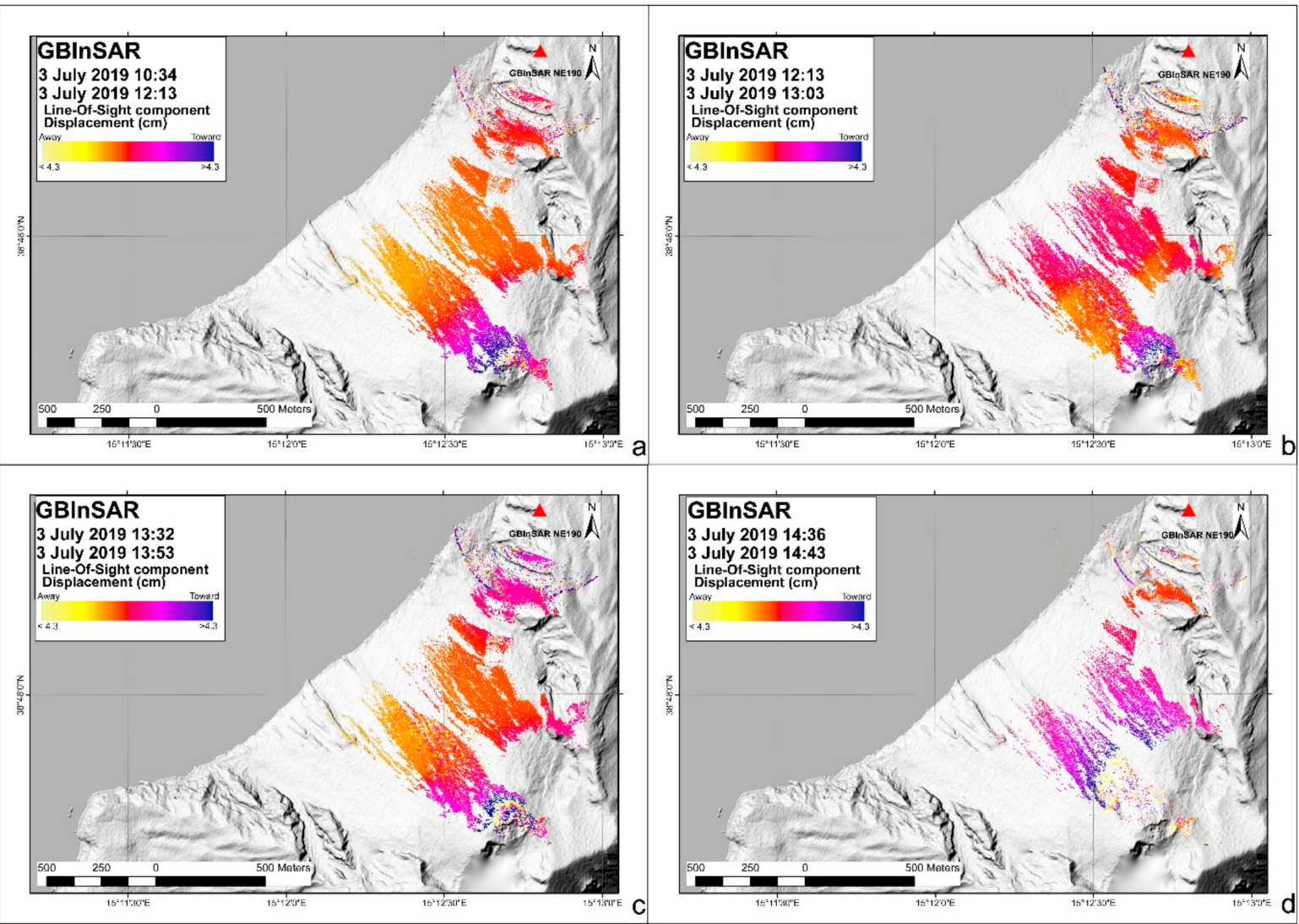

Figure 19. Ground deformation associated with the 3 July 2019 paroxysmal explosion. The interferogram, generated with GB-SAR NE190 system, revealed a progressive increase in the displacement rate, consistent with inflation of the crater terrace. (a) 3 July 2019 10:34-12:13 interferogram; (b) 3 July 2019 12:13-13:03 interferogram; (c) 3 July 2019 13:32-13:53 interferogram; (d) 3 July 2019 14:36-14:43 interferogram. 
During the eruption that began on 3 July 2019 and ended on 30 August 2019, which was characterized by the outpouring of lava from the SW area of the crater terrace $[33,80,81]$, Stromboli underwent some phases of strong explosive activity, with a number of strong Strombolian explosions (on 13 and 15 July 2019), the occurrence of another paroxysmal explosion (28 August 2019), and a major explosion on 29 August 2019. This last event was characterized by two lava fountaining explosive sequences during lava flow output (Tables 3 and 4 and Figure 8). The GBInSAR devices recorded a rapid ground movement towards the sensors (displacement rate: $17.8 \mathrm{~mm} / \mathrm{h}$; Figure 20a), followed by a long movement away from the sensors (max. displacement rate: $6.6 \mathrm{~mm} / \mathrm{h}$ at 03:37 UTC; Figure 20b), compatible with an inflation-deflation cycle that began at 19:42 UTC on 29 August 2019 and ended at 06:04 UTC on 30 August 2019, coinciding with the end of the 2019 effusive eruption.

Afterwards, Stromboli was characterized by intense Strombolian activity, with some lava overflows from the crater terrace, as reported by Calvari et al. [44]. During this period, the radars recorded movements away from the sensors, compatible with the deflation of the crater terrace during some overflow events (31 March 2020; Figure 21).

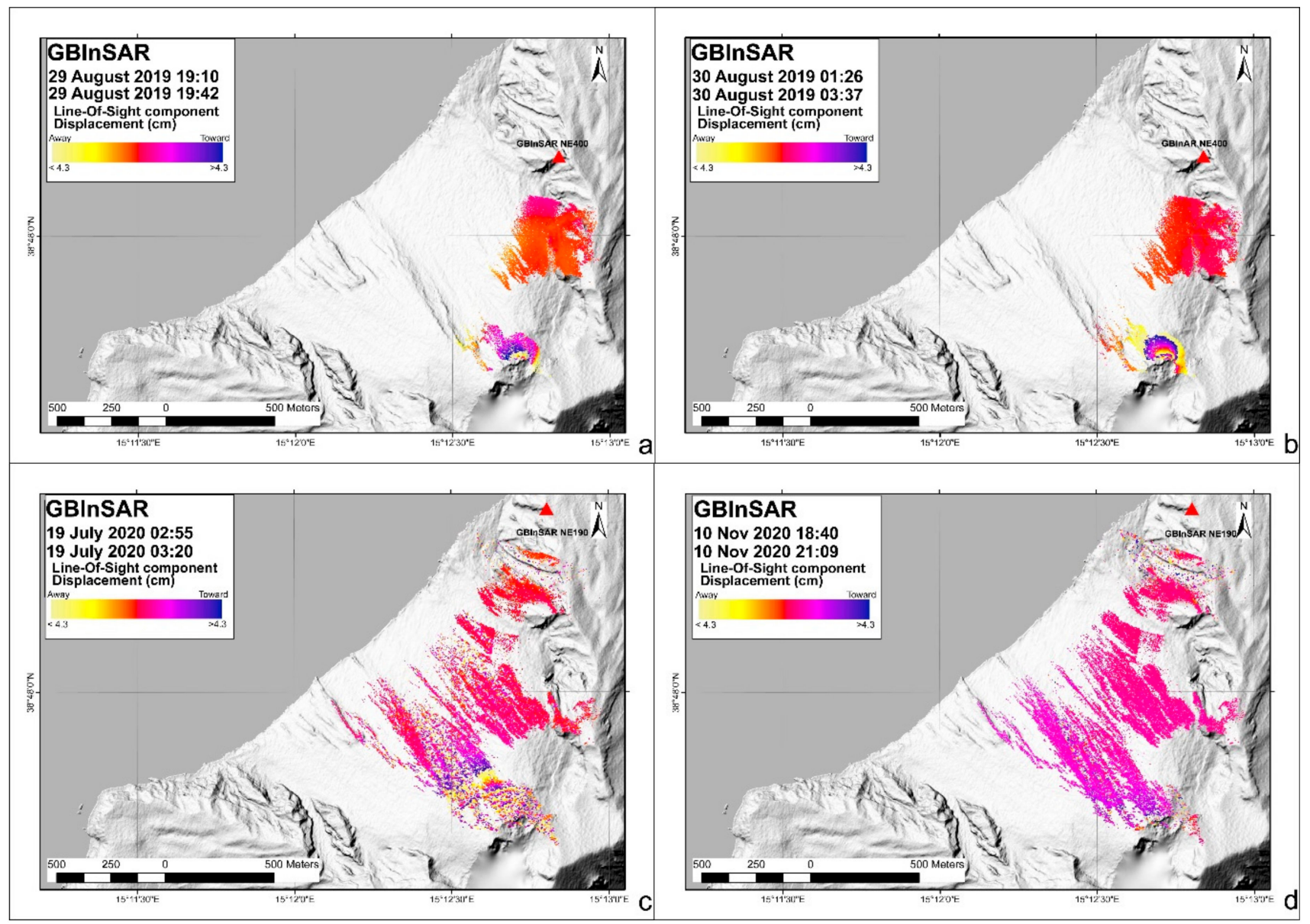

Figure 20. (a) 29 August 2019 (19:10-19:42) interferogram generated with GBInSAR NE400 system; (b) 30 August 2019 (01:26-03:37) interferogram generated with GBInSAR NE400 system; (c) 19 July 2020 (02:55-03:20) interferogram generated with GBInSAR NE190 system; (d) 10 November 2020 (18:40-21:09) interferogram generated with GBInSAR NE190 system. 


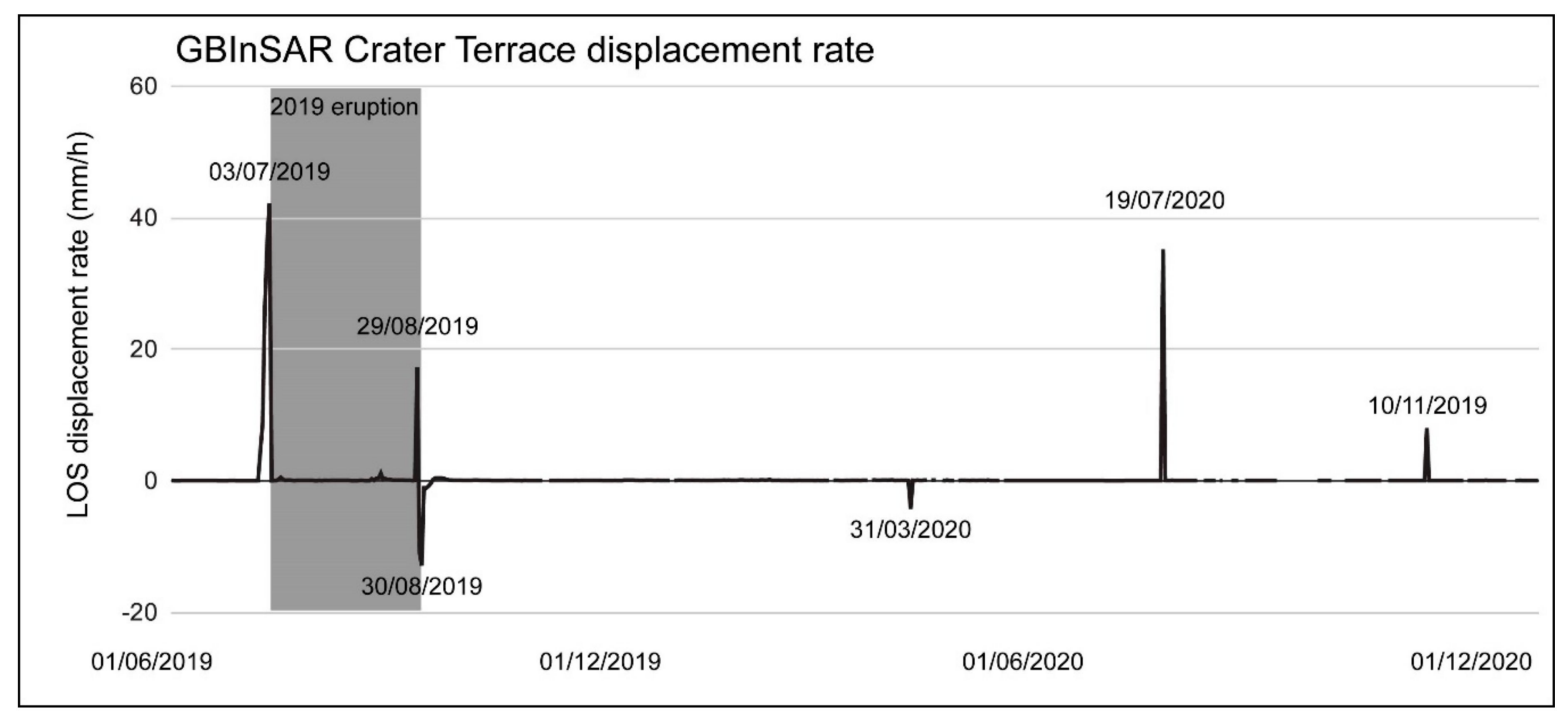

Figure 21. GBInSAR time series, with the 2019 effusive eruption in grey. It can be noted that only 3 explosive events were associated with displacement rate increases toward the sensors (3 July 2019, 19 July 2020, 10 November 2020). The increase in displacement rate, first toward then moving away from the sensors, recorded between 29 August 2019 and 30 August 2019 is associated with a more intense lava flow at the end of the 2019 eruption (inflation-deflation cycle). The signal with displacement rate increases away from the sensor recorded on 31 March 2020 was associated with overflows from the summit craters [44].

The two GBInSAR devices recorded similar deformations, albeit of different magnitudes, during the explosions of 19 July 2020 and 10 November 2020. The former event was associated with a syn-explosive displacement rate of $35.2 \mathrm{~mm} / \mathrm{h}$, whereas the latter was associated with a syn-explosive displacement rate of $8 \mathrm{~mm} / \mathrm{h}$. No deformation prior to the explosive events was recorded, suggesting that the magma volume involved by the two episodes was not large or not detectable.

\section{Discussion}

In the last 140 years, more than 180 high intensity explosive events have been recorded or reported at Stromboli [87], and of these only 44 events have occurred since 2003, when an integrated multiparameter monitoring system was installed on the island [88]. Of the latter, four are rated as paroxysmal explosions and 40 as major explosions [87]. In order to propose a classification scheme, the analysis of our study comprised the 12 explosive events occurring at Stromboli between 25 June 2019 and 6 December 2020. Initially, these 12 explosions were classified as two being paroxysmal (the 3 July 2019 and 28 August 2019) and 10 as major explosions.

In principle, a classification is robust if it is well related to the eruptive mechanisms and characteristics of the explosive events. To this end, we considered both the eruptive style (gas-pyroclast exit speed or muzzle velocity, event duration, height of the eruptive column, impacts, secondary effects), several associated geophysical parameters during the explosion (the magnitude of the VLP size and the tilt changes), as well as the occurrence of a precursor ground deformation signal (dilatometer, GBInSAR).

Among the physical features, an important parameter that can be used to distinguish different sizes of explosions is the height of the eruptive column [82], i.e., the height of the ash plume rising by buoyancy from the crater rim. This height is determined by the intensity of the explosion and thus by the erupted volume [56], and as such is a key discriminant between events of different magnitude and intensity. However, the INGV monitoring cameras available at the moment have a maximum field of view covering a maximum height of $\sim 750 \mathrm{~m}$ above the craters, and thus cannot be used to measure the size of the eruptive columns for all paroxysms $(\mathrm{H}>1 \mathrm{~km})$ and of the strongest major explosions. 
This is why, after considering the maximum height of the eruptive column, we used the muzzle velocity at the vent, considering that the most powerful explosions should also have the highest muzzle velocities, this being a function of the pressure of the expanding gases $[55,82,89]$. In doing so, we have used the images of the SQV monitoring camera (Table 1), which is the only one that recorded all the 12 explosive episodes analysed here. The muzzle velocity is normally attained at the very start of each explosion. An exception to this statement is the 3 July 2019 event, which started with very low speed and reached the peak velocity of $\sim 102 \mathrm{~m} \mathrm{~s}^{-1}$ (Table 4 ) after $\sim 6 \mathrm{~s}$ from the start of the main blast. This was probably caused by the degassed lava contained in the highest portion of the shallow conduit, that was pushed upwards by the gas-rich magma and erupted as lava flows spreading within the crater just before the paroxysm (Figure 4). An additional parameter related to the size of the explosive event is the duration, that can be obtained from the analysis of the videos recorded by the INGV monitoring cameras or by the seismic trace. It is worth mentioning that sometimes it could be difficult to determine this duration, such as in the case of lava fountaining (see for example Figure 8c), where the seismic signal does not show a clear end. It is less difficult from the camera images, although some problems may arise when PDC spreading along the SdF may limit sight. In our investigation the VD parameter, obtained by the multiplication of the muzzle velocities by the event durations $(\mathrm{V} \times \mathrm{D})$, is well-suited to represent the power of explosive activity.

Among the geophysical information considered in this study, the VLP size, as defined by Giudicepietro et al. [33], is the chief parameter allowing us to distinguish between explosive events of different magnitude and intensity. This parameter is sufficient by itself to characterize the power of an explosive event and, moreover, has a clear volcanological correspondence with the VD parameter, as attested by the relationship shown in the graph of Figure 22. This relationship means that we can use any of them or even better a combination of them to classify explosive events at Stromboli.

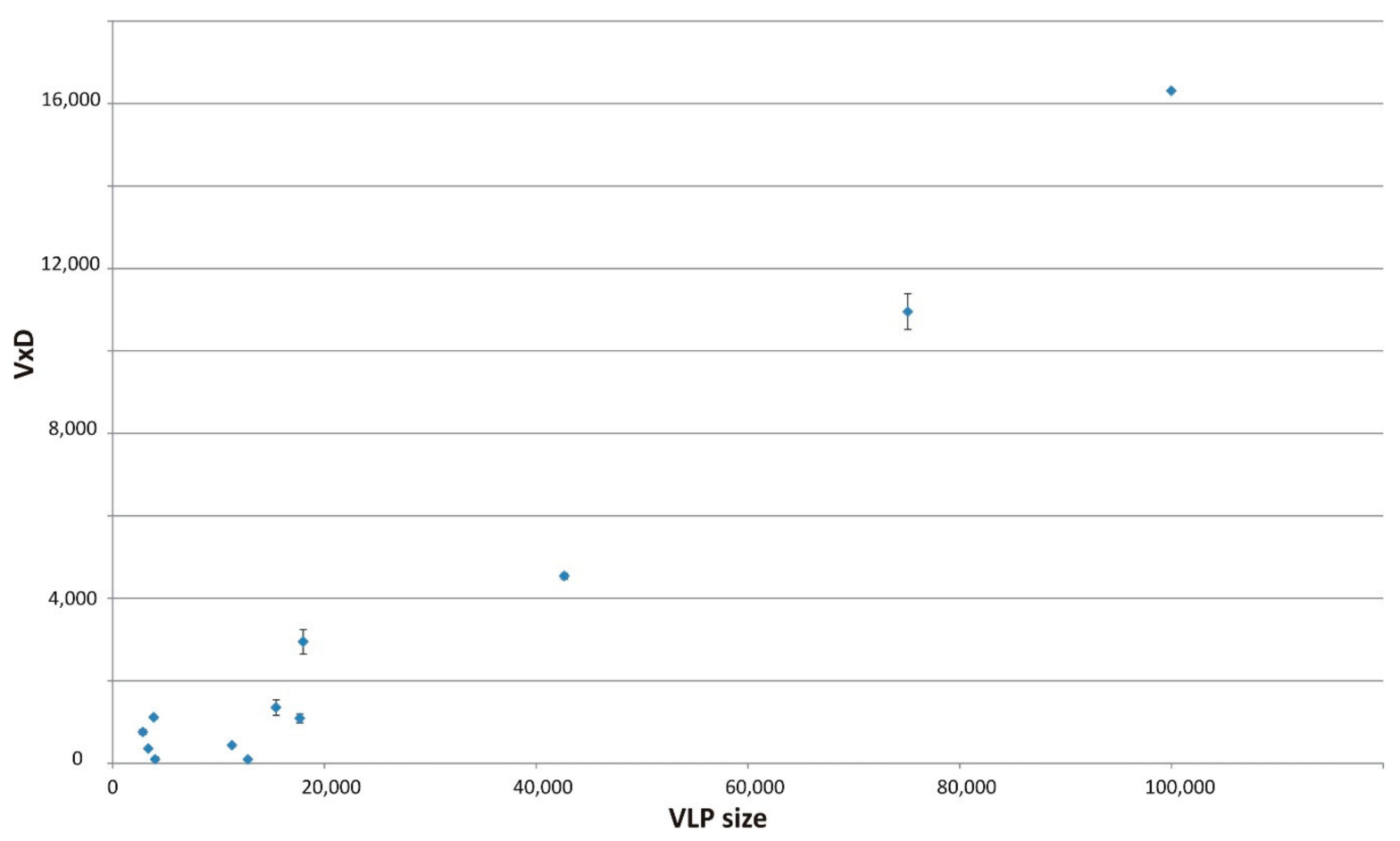

Figure 22. Graph reporting the VLP size vs. the volcanology parameters $(\mathrm{V} \times \mathrm{D})$ obtained multiplying the muzzle velocity $\left(\mathrm{V}\right.$, in $\left.\mathrm{m} \mathrm{s}^{-1}\right)$ of each event by the duration $(\mathrm{D}$, in s). See Table 4 for the list of values.

This interpretative tool provided by the VLP size and by the VD parameter is further supported by the geophysical measurements recorded by the borehole dilatometer and tiltmeter, which for each type of explosive event or class are characterized by a specific range 
of values (Table 5). A complete and useful representation of the integrate classification scheme is shown in Figure 23.

Table 5. Range of the main parameters useful to classify the explosive events of Stromboli.

\begin{tabular}{ccccc}
\hline & \multicolumn{2}{c}{ Classification Scheme of Strombolian Explosions } & 2 & $\mathbf{3}$ \\
\hline Explosion Class & $\mathbf{0}$ & $\mathbf{1}$ & Major & Paroxysmal \\
\hline $\begin{array}{c}\text { Local explosion } \\
\text { classification }\end{array}$ & Ordinary & Intermediate & Crater terrace/rarely \\
top of the volcano & $\begin{array}{c}\text { Top of the volcano/rarely } \\
\text { island sectors }\end{array}$ & $\begin{array}{c}\text { Island sectors/rarely more } \\
\text { distal areas (other islands or } \\
\text { the surrounding coasts) }\end{array}$ \\
\hline $\begin{array}{c}\text { Effect/dispersal area } \\
\text { Jet/plume height (m) }\end{array}$ & Crater terrace & $100-300$ & $300-1000$ & $>1000$ \\
\hline Duration (s) & $<100$ & $20-30$ & $30-100$ & $>100$ \\
\hline Max. speed (m/s) & $<10$ & $10-30$ & $30-70$ & $>70$ \\
\hline VLP size & $<2000$ & $2000-12,000$ & $12,000-18,000$ & $>18,000$ \\
\hline VD parameter & $<90$ & $90-1000$ & $1000-4000$ & $>4000$ \\
\hline Tilt SVO (microstrain) & $\sim 0$ & $\sim 0$ & $\sim 0.05 \times 10^{-6}$ & $\sim 0.5 \times 10^{-6}$ \\
\hline Strain STDF (counts) & $\sim 0$ & $\sim 0$ & $5000-1000$ & $2000-10,000$ \\
\hline
\end{tabular}

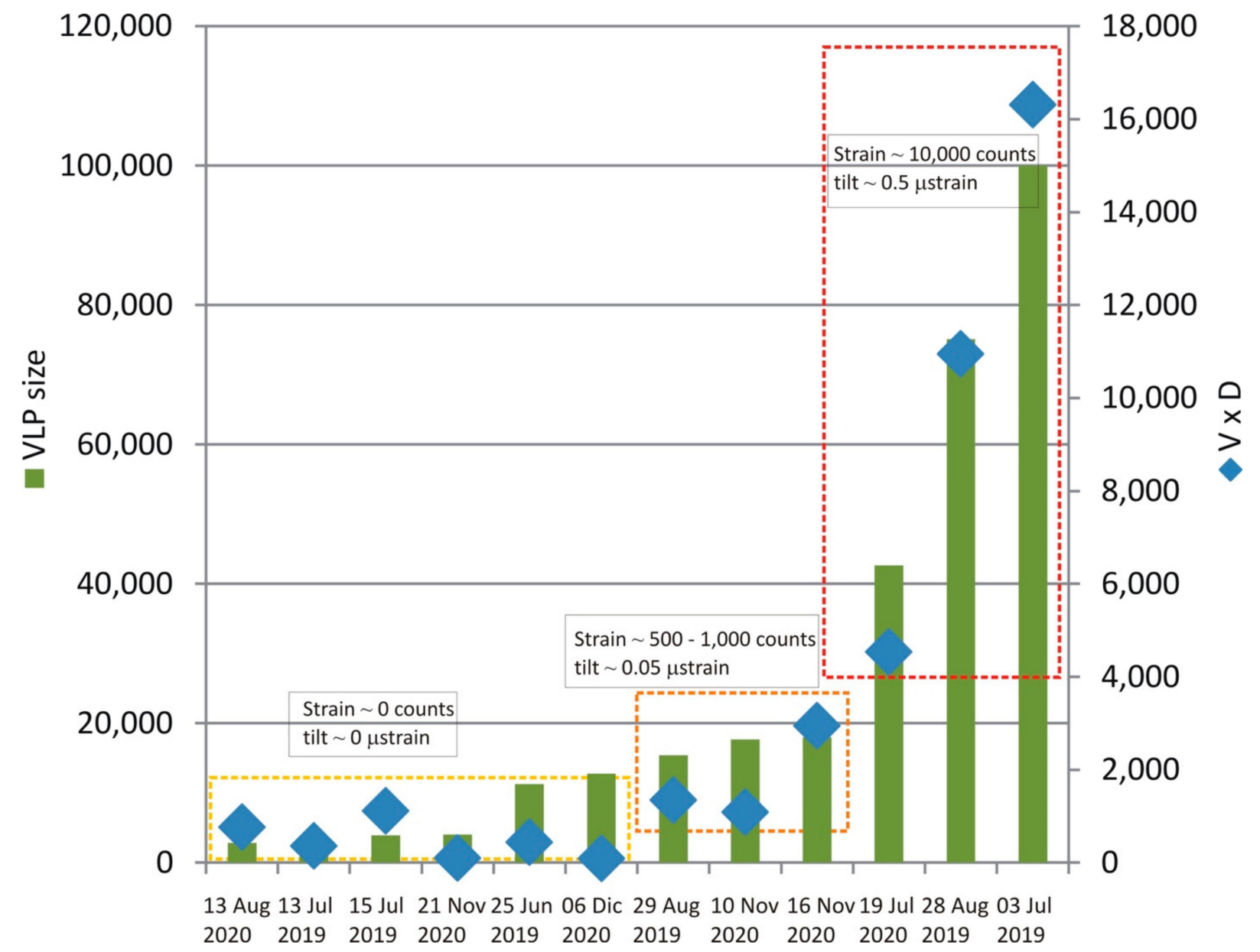

Figure 23. Summarizing diagram showing the classification proposed for the 12 explosive events considered in this paper on the basis of VLP size (left axis), and muzzle velocity by duration (right axis). See text for further explanation. 
It is immediately clear that in this scheme, the explosions of 3 July 2019 and 28 August 2019, defined as paroxysmal explosions, have some characteristics in common (i.e., eruptive plume heights of several km, formation of PDCs along the SdF; high VLP size and strain), albeit with some differences. However, the classification proposed here also raises the explosive event of 19 July 2020 to the rank of paroxysmal explosion, being characterized by a high VLP size $(42,661$, Table 4$)$ and a high VD parameter $(4,537$; Table 4 , Table 5 and Figure 23). The effects of this event affected the summit of the volcano above $500 \mathrm{~m}$ elevation (Table 3) and influenced the NW sector of the island. Fortunately, the material erupted during the explosion fell on the SdF, thus not involving inhabited areas. At the same time, through this classification, we can exclude some events from the list of major explosions (Figure 23), which are therefore to be found in the set of "intermediate" events (13 August 2020, 13 July 2019, 15 July 2019, 25 June 2019, 21 November 2020 and 6 December 2020). These explosions had little or no effects on the summit area of the volcano (i.e., the one where tourists stop to observe the explosive activity). On the contrary, the proper major explosions (29 August 2019, 10 November 2020, and 16 November 2020; Figure 23) had important impacts in terms of ballistic blocks, spatter bombs, and tephra fall on the summit area of the volcano.

\section{Conclusions}

The Strombolian activity of Stromboli volcano was analysed, combining different data from monitoring cameras, seismic network, and ground deformations obtained from different remote sensing and geodetic techniques, in order to obtain a new classification scheme for different explosion intensities.

Considering the distinct sampling frequencies, the best parameters to classify these low but different intensity transient events are the VLP size and the VD parameter. The former is the maximum value of the RSAM of a 30-s sliding window that moves in a 30-min time interval of signal, filtered in VLP frequency band $(0.05-0.5 \mathrm{~Hz})$, whereas the latter is the product of the muzzle velocity and the explosion duration, both derived from the analysis of the monitoring camera images. These parameters are independent of each other and thus can provide the intensity of the event even in absence of the other parameter. The classification scheme identified by these two main parameters is further supported by the indication of the range of values of the dilatometer and tiltmeter recorded during different types of events (Tables 4 and 5). This work demonstrates the importance of multi-parametric monitoring systems as an objective approach towards characterizing events of varying intensity, in the context of the same eruptive style.

Author Contributions: Conceptualization, S.C., F.G. and F.D.T.; methodology, S.C., F.G., F.D.T., G.M. and A.B.; validation, S.C., F.G., F.D.T., G.M. and A.B.; formal analysis, S.C., F.G., F.D.T., G.M. and A.B.; investigation, S.C., F.G., F.D.T., G.M. and A.B.; resources, S.C. and N.C.; data curation, S.C., F.G., F.D.T., G.M. and A.B.; writing-original draft preparation, S.C., F.G., F.D.T., G.M. and A.B.; writing-review and editing, S.C., F.G., F.D.T., G.M. and A.B.; visualization, S.C., F.G., F.D.T., G.M. and A.B.; supervision, S.C., F.G., F.D.T., G.M. and A.B.; project administration, S.C. and N.C.; funding acquisition, S.C. and N.C. All authors have read and agreed to the published version of the manuscript.

Funding: This research was funded by the Project FIRST-ForecastIng eRuptive activity at Stromboli volcano: Timing, eruptive style, size, intensity, and duration, INGV-Progetto Strategico Dipartimento Vulcani 2019, (Delibera n. 144/2020; Scientific Responsibility: S.C.). This work was financially supported by the "Presidenza del Consiglio dei Ministri-Dipartimento della Protezione Civile" (Presidency of the Council of Ministers-Department of Civil Protection) (DPC-UNIFI Agreement 2019-2021; Scientific Responsibility: N.C.). The contents of this paper represent the authors' ideas and do not necessarily correspond to the official opinion and policies of the "Presidenza del Consiglio dei Ministri-Dipartimento della Protezione Civile" (Presidency of the Council of Ministers-Department of Civil Protection).

Acknowledgments: We would like to thank the Commander of the Guardia Costiera di Catania M. Privitera for making available the video recorded during the 3 July 2019 afternoon, and the tourists 
for their videos of the 3 July 2019 and 28 August 2019 events diffused in the internet, because these all furnished important data for the study of these episodes. We would like to acknowledge the essential work of INGV, UNIFI, and Ellegi srl LiSALab technicians for the installation and maintenance of the monitoring networks on Stromboli. We would like to thank Stephan Conway for the correction of the English style.

Conflicts of Interest: The authors declare no conflict of interest.

\section{References}

1. Parfitt, E.A. A discussion of the mechanisms of explosive basaltic eruptions. J. Volcanol. Geotherm. Res. 2004, 134, 77-107. [CrossRef]

2. Harris, A.; Ripepe, M. Temperature and dynamics of degassing at Stromboli. J. Geophys. Res. 2007, 112, B03205. [CrossRef]

3. Patrick, M.R. Dynamics of Strombolian ash plumes from thermal video: Motion, morphology, and air entrainment. J. Geophys. Res. 2007, 112, B06202. [CrossRef]

4. $\quad$ Patrick, M.R.; Harris, A.J.L.; Ripepe, M.; Dehn, J.; Rothery, D.A.; Calvari, S. Strombolian explosive styles and source conditions: Insights from thermal (FLIR) video. Bull. Volcanol. 2007, 69, 769-784. [CrossRef]

5. Leduc, L.; Gurioli, L.; Harris, A.; Colò, L.; Rose-Koga, E.F. Types and mechanisms of strombolian explosions: Characterization of a gas-dominated explosion at Stromboli. Bull. Volcanol. 2015, 77, 8. [CrossRef]

6. Taddeucci, J.; Edmonds, M.; Houghton, B.; James, M.R.; Vergniolle, S. Hawaiian and Strombolian eruptions. In The Encyclopedia of Volcanoes; Elsevier: San Diego, CA, USA, 2015; pp. 485-503.

7. Chouet, B.; Hamisevicz, N.; McGetchin, T.R. Photoballistics of volcanic jet activity at Stromboli, Italy. J. Geophys. Res. 1974, 79, 4961-4976. [CrossRef]

8. Gurioli, L.; Harris, A.J.L.; Colò, L.; Bernard, J.; Favalli, M.; Ripepe, M.; Andronico, D. Classification, landing distribution, and associated flight parameters for a bomb field emplaced during a single major explosion at Stromboli, Italy. Geology 2013, 41, 559-562. [CrossRef]

9. Taddeucci, J.; Alatorre-Ibargüengoitia, M.A.; Cruz-Vázquez, O.; Del Bello, E.; Scarlato, P.; Ricci, T. In-flight dynamics of volcanic ballistic projectiles. Rev. Geophys. 2017, 55, 675-718. [CrossRef]

10. Romagnoli, C. Characteristics and morphological evolution of the Aeolian volcanoes from the study of submarine portions. Geol. Soc. Lond. Mem. 2013, 37, 13-26. [CrossRef]

11. Taddeucci, J.; Palladino, D.M.; Sottili, G.; Bernini, D.; Andronico, D.; Cristaldi, A. Linked frequency and intensity of persistent volcanic activity at Stromboli (Italy). Geophys. Res. Lett. 2013, 40, 3384-3388. [CrossRef]

12. Barberi, F.; Rosi, M.; Sodi, A. Volcanic hazard assessment at Stromboli based on review of historical data. Acta Vulcanol. 1993, 3, 173-187.

13. Calvari, S.; Bonaccorso, A.; Madonia, P.; Neri, M.; Liuzzo, M.; Salerno, G.G.; Behncke, B.; Caltabiano, T.; Cristaldi, A.; Giuffrida, G.; et al. Major eruptive style changes induced by structural modifications of a shallow conduit system: The 2007-2012 Stromboli case. Bull. Volcanol. 2014, 76, 841. [CrossRef]

14. Valade, S.; Lacanna, G.; Coppola, D.; Laiolo, M.; Pistolesi, M.; Delle Donne, D.; Genco, R.; Marchetti, E.; Ulivieri, G.; Allocca, C.; et al. Tracking dynamics of magma migration in open-conduit systems. Bull. Volcanol. 2016, 78, 78. [CrossRef]

15. Aiuppa, A.; de Moor, J.M.; Arellano, S.; Coppola, D.; Francofonte, V.; Galle, B.; Giudice, G.; Liuzzo, M.; Mendoza, E.; Saballos, A.; et al. Tracking formation of a lava lake from ground and space: Masaya volcano (Nicaragua), $2014-2017$. Geochem. Geophys. Geosyst. 2018, 19, 496-515. [CrossRef]

16. Albert, H.; Costa, F.; Di Muro, A.; Herrin, J.; Métrich, N.; Deloule, E. Magma interactions, crystal mush formation, timescales, and unrest during caldera collapse and lateral eruption at ocean island basaltic volcanoes (Piton de la Fournaise, La Réunion). Earth Plan. Sci. Lett. 2019, 515, 187-199. [CrossRef]

17. Albino, F.; Biggs, J.; Escobar-Wolf, R.; Naismith, A.; Watson, M.; Phillips, J.C.; Chigna Marroquin, G.A. Using TanDEM-X to measure pyroclastic flow source location, thickness and volume: Application to the 3rd June 2018 eruption of Fuego volcano, Guatemala. J. Volcanol. Geotherm. Res. 2020, 406, 107063. [CrossRef]

18. Battaglia, J.; Métaxian, J.-P.; Garaebiti, E. Short term precursors of Strombolian explosions at Yasur volcano (Vanuatu). Geophys. Res. Lett. 2016, 43, 1960-1965. [CrossRef]

19. Houghton, B.F.; Taddeucci, J.; Andronico, D.; Gonnermann, H.M.; Pistolesi, M.; Patrick, M.R.; Orr, T.R.; Swanson, D.A.; Edmonds, M.; Gaudin, D.; et al. Stronger or longer: Discriminating between Hawaiian and Strombolian eruption styles. Geology 2016, 44, 163-166. [CrossRef]

20. Rüdiger, J.; Tirpitz, J.-L.; Maarten de Moor, J.; Bobrowski, N.; Gutmann, A.; Liuzzo, M.; Ibarra, M.; Hoffmann, T. Implementation of electrochemical, optical and denuder-based sensors and sampling techniques on UAV for volcanic gas measurements: Examples from Masaya, Turrialba and Stromboli volcanoes. Atmos. Meas. Tech. 2018, 11, 2441-2457. [CrossRef]

21. Spampinato, L.; Ganci, G.; Hernandez, P.A.; Calvo, D.; Tedesco, D.; Perez, N.M.; Calvari, S.; Del Negro, C.; Yalire, M.M. Thermal insights into the dynamics of Nyiragongo lava lake from ground and satellite measurements. J. Geophys. Res. Solid Earth 2013, 118, 5771-5784. [CrossRef]

22. Spampinato, L.; Oppenheimer, C.; Cannata, A.; Montalto, P.; Salerno, G.G.; Calvari, S. On the time-scale of thermal cycles associated with open-vent degassing. Bull. Volcanol. 2012, 74, 1281-1292. [CrossRef] 
23. Vergniolle, S.; Caplan-Auerbach, J. Basaltic thermals and Subplinian plumes: Constraints from acoustic measurements at Shishaldin volcano, Alaska. Bull. Volcanol. 2006, 68, 611-630. [CrossRef]

24. Woitischek, J.; Woods, A.W.; Edmonds, M.; Oppenheimer, C.; Aiuppa, A.; Pering, T.D.; Ilanko, T.; D'Aleo, R.; Garaebiti, E. Strombolian eruptions and dynamics of magma degassing at Yasur Volcano (Vanuatu). J. Volcanol. Geotherm. Res. 2020, 398, 106869. [CrossRef]

25. Pioli, L.; Pistolesi, M.; Rosi, M. Transient explosions at open-vent volcanoes: The case of Stromboli (Italy). Geology 2014, 42, 863-866. [CrossRef]

26. Andronico, D.; Corsaro, R.A.; Cristaldi, A.; Polacci, M. Characterizing high energy explosive eruptions at Stromboli volcano using multidisciplinary data: An example from the 9 January 2005 explosion. J. Volcanol. Geotherm. Res. 2008, 176, 541-550. [CrossRef]

27. Calvari, S.; Büttner, R.; Cristaldi, A.; Dellino, P.; Giudicepietro, F.; Orazi, M.; Peluso, R.; Spampinato, L.; Zimanowski, B.; Boschi, E. The 7 September 2008 Vulcanian explosion at Stromboli volcano: Multi-parametric characterisation of the event and quantification of the ejecta. J. Geophys. Res. Solid Earth 2012, 117, B05201. [CrossRef]

28. Rittmann, A. Der ausbruch des Stromboli am 11 September 1930. Z. Vulkanol. 1931, 14, 47-77.

29. Calvari, S.; Spampinato, L.; Lodato, L. The 5 April 2003 vulcanian paroxysmal explosion at Stromboli volcano (Italy) from field observations and thermal data. J. Volcanol. Geotherm. Res. 2006, 149, 160-175. [CrossRef]

30. Calvari, S.; Lodato, L.; Steffke, A.; Cristaldi, A.; Harris, A.J.L.; Spampinato, L.; Boschi, E. The 2007 Stromboli flank eruption: Chronology of the events, and effusion rate measurements from thermal images and satellite data. J. Geophys. Res. Solid Earth 2010, 115, B04201. [CrossRef]

31. Bonaccorso, A.; Calvari, S.; Linde, A.; Sacks, S.; Boschi, E. Dynamics of the shallow plumbing system investigated from borehole strainmeters and cameras during the 15 March 2007 Vulcanian paroxysm at Stromboli volcano. Earth Plan. Sci. Lett. 2012, 357-358, 249-256. [CrossRef]

32. Giudicepietro, F.; Calvari, S.; Alparone, S.; Bianco, F.; Bonaccorso, A.; Bruno, V.; Caputo, T.; Cristaldi, A.; D’Auria, L.; De Cesare, W.; et al. Integration of Ground-Based Remote-Sensing and In Situ Multidisciplinary Monitoring Data to Analyze the Eruptive Activity of Stromboli Volcano in 2017-2018. Remote Sens. 2019, 11, 1813. [CrossRef]

33. Giudicepietro, F.; Lopez, C.; Macedonio, G.; Alparone, S.; Bianco, F.; Calvari, S.; De Cesare, W.; Delle Donne, D.; Di Lieto, B.; Esposito, A.M.; et al. Geophysical precursors of the July-August 2019 paroxysmal eruptive phase and their implications for Stromboli volcano (Italy) monitoring. Sci. Rep. 2020, 10, 10296. [CrossRef]

34. Pistolesi, M.; Delle Donne, D.; Pioli, L.; Rosi, M.; Ripepe, M. The 15 March 2007 explosive crisis at Stromboli volcano, Italy: Assessing physical parameters through a multidisciplinary approach. J. Geophys. Res. Solid Earth 2011, 116, B12206. [CrossRef]

35. Pistolesi, M.; Rosi, M.; Pioli, L.; Renzulli, A.; Bertagnini, A.; Andronico, D. The paroxysmal event and its deposits. In The Stromboli Volcano: An Integrated Study of the 2002-2003 Eruption; Calvari, S., Inguaggiato, S., Puglisi, G., Ripepe, M., Rosi, M., Eds.; Geophysical Monograph Series; AGU: Washington, DC, USA, 2008; Volume 182, pp. 317-330.

36. Rosi, M.; Bertagnini, A.; Landi, P. Onset of the persistent activity at Stromboli Volcano (Italy). Bull. Volcanol. 2000, 62, 294-300. [CrossRef]

37. Lautze, N.C.; Houghton, B.F. Physical mingling of magma and complex eruption dynamics in the shallow conduit at Stromboli volcano, Italy. Geology 2005, 33, 425-428. [CrossRef]

38. Métrich, N.; Bertagnini, A.; Landi, P.; Rosi, M.; Belhadj, O. Triggering mechanism at the origin of paroxysms at Stromboli (Aeolian Archipelago, Italy): The 5 April 2003 eruption. Geophys. Res. Lett. 2005, 32, L10305. [CrossRef]

39. D'Oriano, C.; Bertagnini, A.; Pompilio, M. Ash erupted during normal activity at Stromboli (Aeolian Islands, Italy) raises questions on how the feeding system works. Bull. Volcanol. 2011, 73, 471-477. [CrossRef]

40. Bertagnini, A.; Di Roberto, A.; Pompilio, M. Paroxysmal activity at Stromboli: Lessons from the past. Bull. Volcanol. 2011, 73, 1229-1243. [CrossRef]

41. Giordano, G.; De Astis, G. The summer 2019 basaltic Vulcanian eruptions (paroxysms) of Stromboli. Bull. Volcanol. 2021, 83, 1. [CrossRef]

42. Calvari, S.; Spampinato, L.; Lodato, L.; Harris, A.J.L.; Patrick, M.R.; Dehn, J.; Burton, M.R.; Andronico, D. Chronology and complex volcanic processes during the 2002-2003 flank eruption at Stromboli volcano (Italy) reconstructed from direct observations and surveys with a handheld thermal camera. J. Geophys. Res. Solid Earth 2005, 110, B02201. [CrossRef]

43. Calvari, S.; Spampinato, L.; Bonaccorso, A.; Oppenheimer, C.; Rivalta, E.; Boschi, E. Lava effusion-A slow fuse for paroxysms at Stromboli volcano? Earth Plan. Sci. Lett. 2011, 301, 317-323. [CrossRef]

44. Calvari, S.; Di Traglia, F.; Ganci, G.; Giudicepietro, F.; Macedonio, G.; Cappello, A.; Nolesini, T.; Pecora, E.; Bilotta, G.; Centorrino, V.; et al. Overflows and Pyroclastic Density Currents in March-April 2020 at Stromboli Volcano Detected by Remote Sensing and Seismic Monitoring Data. Remote Sens. 2020, 12, 3010. [CrossRef]

45. Di Traglia, F.; Nolesini, T.; Intrieri, E.; Mugnai, F.; Leva, D.; Rosi, M.; Casagli, N. Review of ten years of volcano deformations recorded by the ground-based InSAR monitoring system at Stromboli volcano: A tool to mitigate volcano flank dynamics and intense volcanic activity. Earth Sci. Rev. 2014, 139, 317-335. [CrossRef]

46. Di Roberto, A.; Bertagnini, A.; Pompilio, M.; Bisson, M. Pyroclastic density currents at Stromboli volcano (Aeolian Islands, Italy): A case study of the 1930 eruption. Bull. Volcanol. 2014, 76, 827. [CrossRef] 
47. Lodato, L.; Spampinato, L.; Harris, A.J.L.; Calvari, S.; Dehn, J.; Patrick, M. The Morphology and Evolution of the Stromboli 2002-03 Lava Flow Field: An Example of Basaltic Flow Field Emplaced on a Steep Slope. Bull. Volcanol. 2007, 69, 661-679. [CrossRef]

48. Pioli, L.; Rosi, M.; Calvari, S.; Spampinato, L.; Renzulli, A.; Di Roberto, A. The eruptive activity of 28 and 29 December 2002. In The Stromboli Volcano: An Integrated Study of the 2002-2003 Eruption; American Geophysical Union, Geophysical Monograph Series; Calvari, S., Inguaggiato, S., Puglisi, G., Ripepe, M., Rosi, M., Eds.; AGU: Washington, DC, USA, 2008; Volume 182, pp. 105-116. [CrossRef]

49. Di Traglia, F.; Calvari, S.; D'Auria, L.; Nolesini, T.; Bonaccorso, A.; Fornaciai, A.; Esposito, A.; Cristaldi, A.; Favalli, M.; Casagli, N. The 2014 effusive eruption at Stromboli: New insights from in-situ and remote sensing measurements. Remote Sens. 2018, 10, 2035. [CrossRef]

50. Bonaccorso, A.; Calvari, S.; Garfi, G.; Lodato, L.; Patané, D. December 2002 flank failure and tsunami at Stromboli volcano inferred by volcanological and geophysical observations. Geophys. Res. Lett. 2003, 30, 1941-1944. [CrossRef]

51. D'Auria, L.; Giudicepietro, F.; Martini, M.; Peluso, R. Seismological insight into the kinematics of the 5 April 2003 vulcanian explosion at Stromboli volcano (southern Italy). Geophys. Res. Lett. 2006, 33, L08308. [CrossRef]

52. Di Lieto, B.; Romano, P.; Scarpa, R.; Linde, A.T. Strain signals before and during paroxysmal activity at Stromboli volcano, Italy. Geophys. Res. Lett. 2020, 47, e2020GL088521. [CrossRef]

53. Landi, P.; Métrich, N.; Bertagnini, A.; Rosi, M. Recycling and "re-hydration" of degassed magma inducing transient dissolution/crystallization events at Stromboli (Italy). J. Volcanol. Geotherm. Res. 2008, 174, 325-336. [CrossRef]

54. Morrissey, M.M.; Mastin, L.G. Vulcanian Eruptions. In Encyclopedia of Volcanoes; Academic Press: San Diego, CA, USA, 1999; pp. 463-475.

55. Walker, G.P.L. Explosive volcanic eruptions-A new classification scheme. Geol. Rudsch. 1973, 62, 431-446. [CrossRef]

56. Sparks, R.S.J.; Bursik, M.I.; Carey, S.N.; Gilbert, J.S.; Glaze, L.S.; Sigurdsson, H.; Woods, A.V. Volcanic Plumes; John Wiley \& Sons: Chichester, UK, 1997.

57. Calvari, S.; Cannavò, F.; Bonaccorso, A.; Spampinato, L.; Pellegrino, A.G. Paroxysmal Explosions, Lava Fountains and Ash Plumes at Etna Volcano: Eruptive Processes and Hazard Implications. Front. Earth Sci. 2018, 6, 107. [CrossRef]

58. Bonadonna, C.; Pistolesi, M.; Cioni, R.; Degruyter, W.; Elissondo, M.; Baumann, V. Dynamics of wind-affected volcanic plumes: The example of the 2011 Cordón Caulle eruption, Chile. J. Geophys. Res. 2015, 120, 1-20. [CrossRef]

59. Gaudin, D.; Taddeucci, J.; Scarlato, P.; Del Bello, E.; Ricci, T.; Orr, T.; Houghton, B.; Harris, A.; Rao, S.; Bucci, A. Integrating puffing and explosions in a general scheme for Strombolian-style activity. J. Geophys. Res. Solid Earth 2017, 122, 1860-1875. [CrossRef]

60. Newhall, C.G.; Self, S. The Volcanic Explosivity Index (VEI): An Estimate of Explosive Magnitude for Historical Volcanism. J. Geophys. Res. 1982, 87, 1231-1238. [CrossRef]

61. Houghton, B.F.; Swanson, D.A.; Rausch, J.; Carey, R.J.; Fagents, S.A.; Orr, T.R. Pushing the Volcanic Explosivity Index to its limit and beyond: Constraints from exceptionally weak explosive eruptions at Kīlauea in 2008. Geology 2013, 41, 627-630. [CrossRef]

62. Zanon, V.; Neri, M.; Pecora, E. Interpretation of data from the monitoring thermal camera of Stromboli volcano (Aeolian Islands, Italy). Geol. Mag. 2009, 146, 591-601. [CrossRef]

63. Salvatore, V.; Silleni, A.; Corneli, D.; Taddeucci, J.; Palladino, D.M.; Sottili, G.; Bernini, D.; Andronico, D.; Cristaldi, A. Parameterizing multi-vent activity at Stromboli Volcano (Aeolian Islands, Italy). Bull. Volcanol. 2018, 80, 64. [CrossRef]

64. Schmid, M.; Kueppers, U.; Cigala, V.; Sesterhenn, J.; Dingwell, D.B. Release characteristics of overpressurised gas from complex vents: Implications for volcanic hazards. Bull. Volcanol. 2020, 82, 68. [CrossRef]

65. Mills, D.; Martin, J.; Burbank, J.; Kasch, W. Network Time Protocol Version 4: Protocol and Algorithms Specification. RFC 5905. June 2010. Available online: https:/ / www.rfc-editor.org/info/rfc5905 (accessed on 20 January 2021). [CrossRef]

66. De Cesare, W.; Orazi, M.; Peluso, R.; Scarpato, G.; Caputo, A.; D'Auria, L.; Giudicepietro, F.; Martini, M.; Buonocunto, C.; Capello, M.; et al. The Broadband Seismic Network of Stromboli Volcano, Italy. Seismol. Res. Lett. 2009, 80, 435-439. [CrossRef]

67. Orazi, M.; Martini, M.; Peluso, R. Data acquisition for volcano monitoring. Eos Trans. Am. Geophys. Union 2006, 87, 385-392. [CrossRef]

68. Bonaccorso, A. Evidence of a dyke-sheet intrusion at Stromboli volcano inferred through continuous tilt. Geophys. Res. Lett. 1998, 25, 4225-4228. [CrossRef]

69. Bonaccorso, A.; Falzone, G.; Gambino, S. An investigation into shallow borehole tiltmeters. Geophys. Res. Lett. 1999, 26, 1637-1640. [CrossRef]

70. Gambino, S.; Falzone, G.; Ferro, A.; Laudani, G. Volcanic processes detected by tiltmeters: A review of experience on Sicilian volcanoes. J. Volcanol. Geotherm. Res. 2014, 271, 43-54. [CrossRef]

71. Sacks, I.S.; Suyehiro, S.; Evertson, D.W. Sacks-Evertson strainmeter, its installation in Japan and some preliminary results concerning strain steps. Proc. Jpn. Acad. 1971, 47, 707-712. [CrossRef]

72. Martini, M.; Giudicepietro, F.; D'Auria, L.; Esposito, A.M.; Caputo, T.; Curciotti, R.; De Cesare, W.; Orazi, M.; Scarpato, G.; Caputo, A.; et al. Seismological monitoring of the February 2007 effusive eruption of the Stromboli volcano. Ann. Geophys. 2007, 50, 775-788.

73. Antonello, G.; Casagli, N.; Farina, P.; Leva, D.; Nico, G.; Sieber, A.J.; Tarchi, D. Ground-based SAR interferometry for monitoring mass movements. Landslides 2004, 1, 21-28. [CrossRef] 
74. Di Traglia, F.; Battaglia, M.; Nolesini, T.; Lagomarsino, D.; Casagli, N. Shifts in the eruptive styles at Stromboli in 20102014 revealed by ground-based InSAR data. Sci. Rep. 2015, 5, 13569. [CrossRef]

75. Rudolf, H.; Leva, D.; Tarchi, D.; Sieber, A.J. A mobile and versatile SAR system. In Proceedings of the IEEE 1999 International Geoscience and Remote Sensing Symposium, IGARSS'99 (Cat. No.99CH36293), Hamburg, Germany, 28 June-2 July $1999 ;$ pp. 592-594.

76. Monserrat, O.; Crosetto, M.; Luzi, G. A review of ground-based SAR interferometry for deformation measurement. ISPRS J. Photogramm. Remote Sens. 2014, 93, 40-48. [CrossRef]

77. Calvari, S.; Intrieri, E.; Di Traglia, F.; Bonaccorso, A.; Casagli, N.; Cristaldi, A. Monitoring crater-wall collapse at active volcanoes: A study of the 12 January 2013 event at Stromboli. Bull. Volcanol. 2016, 78, 1-16. [CrossRef]

78. Casagli, N.; Tibaldi, A.; Merri, A.; Del Ventisette, C.; Apuani, T.; Guerri, L.; Fortuny-Guasch, J.; Tarchi, D. Deformation of Stromboli Volcano (Italy) during the 2007 eruption revealed by radar interferometry, numerical modelling and structural geological field data. J. Volcanol. Geotherm. Res. 2009, 182, 182-200. [CrossRef]

79. Schaefer, L.N.; Di Traglia, F.; Chaussard, E.; Lu, Z.; Nolesini, T.; Casagli, N. Monitoring volcano slope instability with Synthetic Aperture Radar: A review and new data from Pacaya (Guatemala) and Stromboli (Italy) volcanoes. Earth Sci. Rev. 2019, 192, 236-257. [CrossRef]

80. Marchese, F.; Genzano, N.; Neri, M.; Falconieri, A.; Mazzeo, G.; Pergola, N. A Multi-Channel Algorithm for Mapping Volcanic Thermal Anomalies by Means of Sentinel-2 MSI and Landsat-8 OLI Data. Remote Sens. 2019, 11, 2876. [CrossRef]

81. Genzano, N.; Pergola, N.; Marchese, F. A Google Earth Engine Tool to Investigate, Map and Monitor Volcanic Thermal Anomalies at Global Scale by Means of Mid-High Spatial Resolution Satellite Data. Remote Sens. 2020, 12, 3232. [CrossRef]

82. Carey, S.N.; Sparks, R.S.J. Quantitative models of the fallout and dispersal of tephra from volcanic eruption columns. Bull. Volcanol. 1986, 48, 109-125. [CrossRef]

83. Neuberg, J.; Luckett, R.; Ripepe, M.; Braun, T. Highlights from a seismic broadband array on Stromboli volcano. Geophys. Res. Lett. 1994, 21, 749-752. [CrossRef]

84. Chouet, B.; Dawson, P.; Ohminato, T.; Martini, M.; Saccorotti, G.; Giudicepietro, F.; De Luca, G.; Milana, G.; Scarpa, R. Source mechanisms of explosions at Stromboli volcano, Italy, determined from moment-tensor inversions of very- long-period data. J. Geophys. Res. 2003, 108, 2019. [CrossRef]

85. Giudicepietro, F.; Auria, L.D.; Martini, M.; Caputo, T.; Peluso, R.; de Cesare, W.; Orazi, M.; Scarpato, G. Changes in the VLP seismic source during the 2007 Stromboli eruption. J. Volcanol. Geotherm. Res. 2009, 182, 162-171. [CrossRef]

86. Bonaccorso, A.; Gambino, S.; Guglielmino, F.; Mattia, M.; Puglisi, G.; Boschi, E. Stromboli 2007 eruption: Deflation modeling to infer shallow-intermediate plumbing system. Geophys. Res. Lett. 2008, 35, L06311. [CrossRef]

87. Bevilacqua, A.; Bertagnini, A.; Pompilio, M.; Landi, P.; Del Carlo, P.; Di Roberto, A.; Aspinal, W.; Neri, A. Major explosions and paroxysms at Stromboli (Italy): A new historical catalog and temporal models of occurrence with uncertainty quantification. Sci. Rep. 2020, 10, 17357. [CrossRef]

88. Bertolaso, G.; Bonaccorso, A.; Boschi, E. Scientific Community and Civil Protection Synergy during the Stromboli 2002-2003 Eruption. In The Stromboli Volcano: An Integrated Study of the 2002-2003 Eruption; AGU Geophysical Monograph Series; AGU: Washington, DC, USA, 2008; pp. 387-397. [CrossRef]

89. McBirney, A.R. Factors Governing the Intensity of Explosive Andesitic Eruptions. Bull. Volcanol. 1973, 37, 443-453. [CrossRef] 